\title{
26. POROSITY, DENSITY, GRAIN DENSITY, AND RELATED PHYSICAL PROPERTIES OF SEDIMENTS FROM THE RED SEA DRILL CORES ${ }^{1}$
}

\author{
Frank T. Manheim, Linda Dwight, and Rebecca A. Belastock,
} United States Geological Survey, Woods Hole, Massachusetts

\section{INTRODUCTION}

Representative sediments from each site were chosen for examination of their dry specific gravity and grain density. The determinations were made by micropycnometer; water was used as the displacing medium, and salt corrections were based on the refractive index measurements on interstitial water. For saltier brines the "salinities" derived from index of refraction are somewhat too low but, for the most part, are adequate for these corrections. Water contents are those determined on the archived samples selected for these studies. They had been kept in cold storage $\left(4^{\circ} \mathrm{C}\right)$ in screw-capped glass bottles with polyseal lids or in heat-sealed polyethylene bags for a period of about three months.

The purpose of the measurements was to gain sufficient information on grain density to permit application of the general information or pattern to the bulk water content determinations on the small syringe samples. Bulk density, porosity, and other properties could then be calculated without using volume measurements from the syringes. Whereas the data from weight loss on drying (bulk water content) at $110-120^{\circ}$ were considered good, the volume measurements are subject to considerable error, especially in more consolidated sediments, and are not usable at all for shales, more consolidated or cemented rocks, and anhydrite.

Detailed comparisons with the GRAPE determinations were also an objective. The Red Sea cores offer a particularly good opportunity to test the validity of these measurements, which have been increasingly questioned.

\section{APPLICABLE FORMULAE}

Specific Gravity of Dried Sediment

$$
S p G=\frac{x}{a+x-b}
$$

where:

$x$ is sample weight (after drying),

$a$ is the weight of the water-filled pycnometer, and

$b$ is the weight of the sediment-water-filled pycnometer

$x$ in this case is the weight of the sediment plus the dried interstitial salt. The $b$ term also contains an $x$ plus the dried salt. Therefore, equation (1) gives the specific gravity of dried sediment residue.

Correction for salt: Correction for salt can be made in three steps.

\footnotetext{
${ }^{1}$ Contribution No. 3194 of the Woods Hole Oceanographic Institution,
}

$$
w=\frac{W x}{100-W}
$$

where:

$W$ is water content as a percent of bulk weight and

$w$ is the weight of water in the initial wet sediment, corresponding to the weight of $x$

$$
s=\frac{S w}{100-S}
$$

where:

$s$ is the weight of salt in the initial wet sediment, corresponding to $x$ and

$S$ is the salt concentration, expressed in percent, of the interstitial brine in the sample.

Correction for salt in equation (1) is now given by equation (4).

$$
(S p G)_{b}=\frac{x-s}{A-\frac{s}{(S p G)_{s}}}
$$

where:

$A=a+x-b=$ the volume of dried sediment,

$(S p G)_{b}=$ grain density of the sediment at $4^{\circ} \mathrm{C}$, or specific gravity corrected for salt, and

$(S p G)_{S}=$ specific gravity of the salt residue, determined to be about 2.26 for Copenhagen water, in our experiments.

Some verbalizations of the equations given may be helpful since the volume-density relationships are often confusing. Equation (1) corresponds to weight divided by volume. The weight of the pycnometer bottle and its contained sediment weight cancel out of the denominator of the equation leaving only water weight of the full pycnometer bottle less the water remaining after the contained sediment displaces its volume. The difference is the weight of the displaced water. Since most measurements are made at room temperature, the fluid weight is divided by its density at the measurement temperature to give sediment volume. Water density is about .997 at $25^{\circ} \mathrm{C}$. Change in volume of solids with temperature is ignored as insignificant.

To make the salt correction, the ratio of water content $(W)$ to weight of sediment plus salt $(100-W)$ is multiplied by the dry weight of sediment emplaced in the pycnometer. This gives original water weight $(w)$ corresponding to the emplaced sediment $(x)$ (equation 2). In like manner, the salt corresponding to $x$ is given by the ratio of salt concentration of the interstitial water $(S)$ to the weight of 
the water alone $(100-S)$ multiplied by the weight of water $(w)$ corresponding to $x$. The interstitial salinity is obtained from actual measurements on board, or, if the sediment comes from intermediate depths, by interpolation into an interstitial salinity-depth curve.

Equation (4) is obtained by subtracting from the total dried sediment $(x)$ the corresponding weight of salt from equation (3). Since, in the denominator, $b$ also contains an $x$ term, $x-s$ cancels out. However, the weight of displaced water must be decreased by the volume of the salt. This is given by $s /(S p G)_{s}$. For normal (Copenhagen) seawater we have determined $S p G_{S}$ to be about 2.26, whereas, for rock salt the specific gravity is given as 2.16 in handbooks.

\section{GRAIN DENSITY DETERMINATION}

Specific gravity (grain density) determinations were made for selected samples from Leg 23 (Table 1). The results of the grain density determinations can be interpreted in the light of specific gravity for the mineral phases observed in the Leg 23 samples (Table 2).

The model grain density for most sediments in Sites 225, 227 , and 228 was on the order of 2.75 if both evaporitic sediments and several unusually light samples were excluded. Examination of the mineralogy (Stoffers and Hathaway, this volume) of the light samples indicated that cristobalite and, to a lesser extent, palygorskite were probably responsible for the unusually low grain densities. These minerals appear to result from the weathering of volcanic ash. The iron-rich and metalliferous mud from Site 226 had a specific gravity of 3.02 , which is attributable to the combined presence of iron-montmorillonite, some iron oxide, and metal sulfide phases. Anhydrite was largely absent from the samples chosen for pycnometer determination.

Many samples from Sites 225 through 228 showed salt-corrected specific gravities higher than 2.75 , ranging to 2.88 , for the dried sediment. These values exclude evaporitic sediments, which had specific gravities commensurate with the local mixture of anhydrite, halite, and other constituents. The mineral phases that may contribute to the rather high specific gravities include dolomite; iron-rich chlorites and, possibly, montmorillonites; pyrite; and heavy minerals resulting from weathering of basaltic rocks, such as amphiboles and pyroxenes, ilmenite and magnetite, and in some cases, goethite. Manganese was generally not prominent except in an unusual ankeritic rock in Sample 225-22, CC (Table 1) and in the mineralized black shales in the evaporitic section of Site 228 (Core 39). Dolomite occurs in small quantities throughout the cores and becomes prominent in or just above the evaporitic sequences.

\section{CALCULATION OF POROSITY, DENSITY, AND OTHER SEDIMENT PROPERTIES}

Data on water loss, interstitial salinity, and grain density permit calculation of a variety of pertinent parameters. These are given in the formulae below.

$$
S^{\prime}=\frac{S W}{(100-S)}
$$

where:

$S^{\prime}$ is salt from the interstitial water, expressed as a percent of bulk sediment,

$W$ is water loss on heating at $110^{\circ}-120^{\circ} \mathrm{C}$, as a percent of bulk sediment, and

$S$ is total salt content of brine, expressed as a weight percent.

$$
D=\frac{100}{\frac{\text { (wt. sed. }+ \text { salt })}{S p G_{a}}+W}=\frac{100}{\frac{(100-W)}{S p G_{a}}+W}
$$

where:

$D$ is the bulk density or weight of bulk sediment/volume and

$S p G_{a}$ is the specific gravity of dried sediment (including salt).

$$
P=\frac{\left.W+S^{\prime} / S p G_{S}\right)}{\frac{(100-W)}{S p G_{a}}+W}=\frac{D\left(W+S^{\prime} / S p G_{S}\right)}{100}
$$

where:

$P$ is the porosity, or volume of pores (brine-filled)/total volume and

$S p G_{S}$ is the specific gravity of the dried salt residue $\left(110^{\circ}-120^{\circ} \mathrm{C}\right)$.

$$
\left.B=\frac{W+S^{\prime}}{100}=W / 100-S\right)
$$

where:

$B$ is brine content of bulk sediment (percent).

$$
W^{\prime}=W /\left(100-S^{\prime}-W\right)
$$

where:

$W^{\prime}$ is water content expressed as a percent of dry weight of sediment (brine free).

$$
b=\frac{W+S^{\prime}}{(100-W)}
$$

where:

$b$ is brine content of the sediment, expressed as a percent of the dried sediment (including salt).

The specific gravity of sea salt $=2.26$ according to pycnometer measurements on dried Copenhagen standard water. The specific gravity for halite is given as 2.17 or 2.16. Accordingly, 2.2 can be substituted for $S p G_{S}$ for most interstitial waters.

Strictly speaking, values of $D$ and $P$ are valid for $4^{\circ} \mathrm{C}$, since at that temperature the weight of $1 \mathrm{~g}$ of water corresponds to $1 \mathrm{~cm}^{3}$ volume. At other temperatures, the weight of the water would have to be converted to volume by dividing by water density, and the specific gravity terms would have to be altered to density at the given temperature. In practice, these changes would not be significant compared to natural variability of sediments. Moreover, the parameters given here ignore the compressibility of water at 
depth and measure only the physical properties of the sediment on deck under atmospheric pressure. We can expect some expansion and reorientation of cores as they are moved from the abyssal depths to the surface. The change in specific volume of seawater having salinity of 40 $\%$ decreases from $.9735 \mathrm{~cm}^{3} / \mathrm{g}$ at $25^{\circ} \mathrm{C}$ and $1 \mathrm{~atm}$. to $.9706 \mathrm{~cm}^{3} / \mathrm{g}$ at $40^{\circ} \mathrm{C}$ and 200 atmospheres (W. Wilson and D. Bradley, cited in Horne, 1966, p. 481). Thus, where $W$ (water loss) is converted to volume in equations (5) through (10), in situ densities of water corresponding to conditions at depths on the order of $2200 \mathrm{~m}$ would reduce volumes for $W$ as calculated for room temperature and normal atmospheric conditions by about .5\%. For very concentrated brines the error would be less.

\section{COMPARATIVE STUDIES}

\section{Syringe-volume Based Porosity Values}

Past observers have repeatedly noted serious errors in porosity data obtained from volume information gained through use of cutoff, disposable syringes as sampling devices. Even with care, the syringe samples tend to entrain air pockets or selectively sample softer deformed slush rather than firmer undeformed sediment. This tendency to obtain porosities that are systematically too large becomes progressively greater with increasing consolidation. More consolidated materials cannot be sampled at all. Table 3 illustrates typical scatter of values under relatively optimum conditions. A Physical Properties Panel meeting for JOIDES, May 27, 1971, concluded that the small syringe system resulted in questionable data and recommended that it be revised or replaced (Keller, written communication, 1971). For the above reasons, no syringe-volume-based porosities are recorded here.

The Physical Properties Panel also regarded use of generally less than 1-g samples obtained by the small (1 $\mathrm{cm}^{3}$ ) syringes as undesirably small. However, if the serious errors associated with reliance on syringe volumes are removed, experiments performed by the Woods Hole interstitial water group suggest that the syringe samples or other comparably small samples can yield values that compare reasonably well with larger samples in terms of water content. This will be demonstrated in the following section. The ability to use small samples for water content determination is important because of the convenience and practicability of weighing aboard a moving ship using a small-capacity electrobalance.

\section{Water Determination and Derivative Porosity and Values}

Weighing tests using the shipboard balances (Cahn Electrobalance) show that weighing accuracies of about 1 percent relative error or less can be achieved routinely except in high sea states (Keller, written communication, 1971; Boyce, unpublished memorandum, 1972). By utilizing determination of water content by weight loss after heating at $110^{\circ}-120^{\circ} \mathrm{C}$, studies by the Woods Hole interstitial water group of Leg 4 samples have shown reasonably satisfactory agreement between water content values obtained from syringe or other small shipboard samples (usually on the order of $0.5 \mathrm{~cm}^{3}$ ) and $5-10 \mathrm{~g}$ samples. The latter were carefully packed in small, special glass jars with conical polyethylene cap liners (Polyseal@) and were sent to the shore laboratory for analysis. The samples were taken from the same core section and interval and lithologic type as the small samples. Results are shown in Table 3. Whereas a few samples predictably show more than 10 percent difference, most agree within a few percent water content, and, equally important, no tendency for systematic bias is evident.

Porosity and bulk density are more useful than water content for many purposes, including estimate of permeability, diffusion properties, and geophysical properties of sediments. To calculate these using the formulas given earlier, the grain density of the solid portion of the sediment and the salinity (total dissolved solid content) of the pore fluid are needed. Given these parameters, values are obtained whose reliability is governed chiefly by degree of freedom from disturbance or contamination of the original sample. The small samples are especially valuable here, for one can use discretion in avoiding obviously disturbed, pasty outer sections of cores and select even relatively small islands of apparently undeformed material.

Representative lithologies were sampled as noted in the preceding sections for grain density measurements by micropycnometer. These were then applied or interpolated to the full column to provide grain density measurement for porosity and density calculations (Tables 4 through 8 ).

Gamma Ray Attenuation Porosity Evaluator (GRAPE) Method for Determining Physical Properties

The theory and practice of shipboard use of the GRAPE device have been dealt with in detail in shipboard manuals and in Boyce (in press) and need not be repeated here. The method is unquestionably powerful when properly calibrated and suited to the problem. The question to be dealt with here is its utility and validity as a routine measurement under existing shipboard conditions.

The GRAPE measurements are based on a pencildiameter gamma ray beam directed transversely through a core in its plastic liner, the core moving slowly across the beam path. As pointed out by Boyce (in press), sources of error are inherent in existing shipboard practice because the unopened core includes undisturbed sediment, disturbed sediment, drilling slurries, and possibly also air or gas in variable and unpredictable amounts. Only maximum wet-bulk density values and corresponding minimum porosity values are regarded by Boyce as probably valid. Other potential errors include variations in size of core barrel or liner and mineral properties.

A factor relating to the utility of the method is that the slow scan through the GRAPE detector must be performed before the core is cut for lithologic analysis or sampling; hence, where coring is continuous as in the Red Sea, the GRAPE measurement may delay processing of cores for as much as several hours.

Finally, the complex calibration and correction systems require computer processing at the Scripps facility under the supervision of skilled practitioners. To obtain theoretically accurate porosity and density values grain density and mineral character information must be separately determined. In this respect, the GRAPE resembles the water content approach. 
TABLE

Specific Gravity (Grain Density) Determination

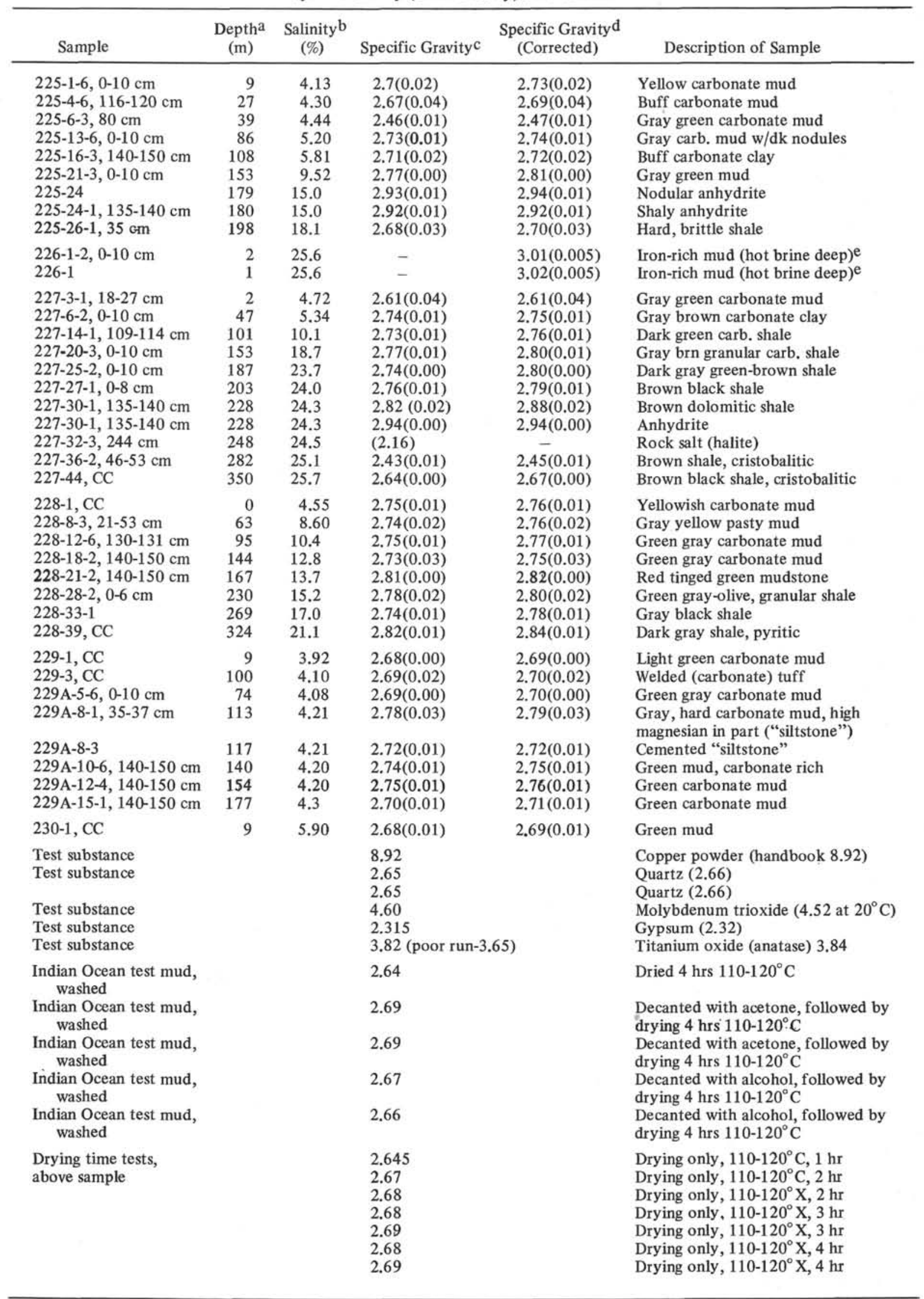


TABLE 1 - Continued

\begin{tabular}{|c|c|c|c|c|c|}
\hline Sample & $\begin{array}{c}\text { Deptha } \\
\text { (m) }\end{array}$ & $\begin{array}{l}\text { Salinityb } \\
(\%)\end{array}$ & Specific Gravityc & $\begin{array}{l}\text { Specific Gravityd } \\
\text { (Corrected) }\end{array}$ & Description of Sample \\
\hline Acetone decanted & & & 2.68 & & Dried $110-120$ \\
\hline Acetone decanted & & & 2.70 & & Dried $110-120^{\circ}, 1 \mathrm{hr}$ \\
\hline Acetone decanted & & & 2.69 & & Dried $110-120^{\circ}, 2 \mathrm{hr}$ \\
\hline Acetone decanted & & & 2.70 & & Dried $110-120^{\circ}, 2 \mathrm{hr}$ \\
\hline Acetone decanted & & & 2.71 & & Dried $110-120^{\circ}, 3 \mathrm{hr}$ \\
\hline Acetone decanted & & & 2.69 & & Dried $110-120^{\circ}, 3 \mathrm{hr}$ \\
\hline
\end{tabular}

Note: Weights of sample used for the pycnometer determinations are between 0.1 and 0.5 grams. Values in parenthesis are spread of duplicate determinations from the mean.

aDepth from sea floor.

bSalinity of interstitial water (in percent, rather than the more normal per mil).

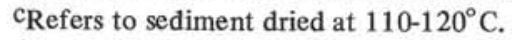

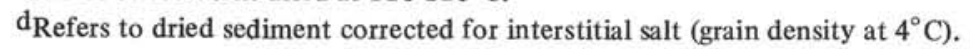

${ }^{\mathrm{e}}$ Leached free of salt with distilled water.

In the preparation of Tables 4 through 7 and Figures 1 through 5, the precise locations assigned to the water content samples were related to the computer log of GRAPE properties and a mean of values $2 \mathrm{~cm}$ on either side of the appropriate locations was employed as "local" values for correlation. The section means are listed together in Table 8 with the local values for comparison. Since locations for water content samples were selected for minimum disturbance, it follows that GRAPE values from such areas ought to be more reliable than whole section means.

\section{Results of Comparison}

The Red Sea cores offer one of the most detailed opportunities for studying sediment physical properties yet obtained in the DSDP program. Reasons for this include the fact that continuous coring was mandated, sediments varied in porosity from nearly 80 percent to less than 1 percent, and an intensive effort was made to sample both frequently and judiciously. Comprehensive pore fluid data were also available for the purpose of salt corrections.

The results of the laboratory and GRAPE porosity comparisons shown in Tables 4 through 7 and Figures 1 through 5 fully bear out the caveats given by Boyce (in press). A statistical analysis of the correlations (Table 9) shows a very poor correlation between the two sets of data, taken as a whole. The null hypothesis that the $a$ (intercept) values do not include 0 for the equation, $y=a+b x$ is rejected only for confidence limits off scale on standard statistical charts (i.e., $>0.995$ ) for all sites except 227 . This means that there is a significant systematic bias between the data sets, the GRAPE values being larger.

The Student's $t$ test likewise gives a similar result for slope. In spite of the scatter (and hence very large tolerance limits) only Site 227 yields the possibility of a slope denoting a 1:1 correlation between GRAPE and water content-based porosities at the 95 percent confidence level.

One should bear in mind that, while not necessarily ideal, the water content-based samples have the closest approach available to valid samples and freedom from significant systematic error. The consistent trends in composition of interstitial water extracted from samples chosen in a similar way also lends independent support to the concept that the geologist's (geochemist's) eye can discern samples free enough from disturbance to minimize (though not invariably eliminate) contamination with drilling fluid.

In spite of the above, Sites 225, 227, 228, and 229 do show certain sections (e.g., 45-57 m, 133-170 m in Figure 5 , Site 225) where correspondence between the two sets of data is good. Similar agreements have been observed by other workers in earlier legs and may be partly responsible for a reluctance to discontinue the GRAPE measurements in spite of recurrent questions on their usefulness to the DSDP program.

\section{DISCUSSION AND CONCLUSIONS}

1. In the course of the DSDP the disturbance of physical properties of sediments has been noted too often to require detailed documentation here. Both syringederived porosities (utilizing volume data) and GRAPE tend to record values heavily influenced by artificial factors in irregular and rather unpredictable ways. They have not yielded reliable or consistent measures of true porosity or density of penetrated strata in Leg 23B. We believe that they probably have not delivered valid results in most prior DSDP sites. We recognize that the quality of physical property data may be better in those sites where workers especially concerned or experienced with these properties have made special ancillary measurements (e.g., grain density); have taken special pains with instrument calibration; or otherwise attempted to test the validity of the measurements. Particularly significant contributions to the questions of sediment porosity and related parameters include work by Gealy and Gerard (1970), Gealy (1971), Bennett and Keller (1973), and Boyce (in press).

One argument for retaining GRAPE measurements in the face of recurrent questions and criticisms is that GRAPE data "is good except where it is bad." The difficulty with this argument is that the goodness or badness has been established only with the aid of methods that are inherently less subject to some of the known practical difficulties affecting shipboard use of GRAPE. These methods are chiefly water content measurements accompanied by grain density data, or in cases of consolidated or crystalline rocks, total weighing and displacement. If GRAPE values 
TABLE 2

Specific Gravity of Selected Minerals

\begin{tabular}{|c|c|}
\hline Mineral & Specific Gravity \\
\hline Carnallite $\left(\mathrm{KMgCl}_{3} \cdot 6 \mathrm{H}_{2} \mathrm{O}\right)$ & 1.60 \\
\hline Tachyhydrite $\left(\mathrm{CaM}_{\mathrm{gCl}} \cdot 12 \mathrm{H}_{2} \mathrm{O}\right)$ & 1.67 \\
\hline Halite & $2.16-2.17$ \\
\hline Analcite & $2.22-2.29$ \\
\hline Opal (amorphous silica) & 2.2 \\
\hline Palygorskite & $2.29-2.36$ \\
\hline Cristobalite & 2.32 \\
\hline Gypsum & 2.32 \\
\hline K feldspar & 2.54 \\
\hline $\begin{array}{l}\text { Montmorillonite (dehydrated) } \\
(3.6 \% \text { fe } 2.74)\end{array}$ & $2.53->2.75$ \\
\hline Kaolinite & 2.63 \\
\hline Illite & $2.64-2.69$ \\
\hline $\begin{array}{l}\text { Chlorite (magnesian) } \\
\text { (Fe-chlorite, daphnite) }\end{array}$ & $\begin{array}{c}2.62 \\
(3.09)\end{array}$ \\
\hline Quartz & 2.651 \\
\hline $\begin{array}{l}\text { Calcite } \\
\text { (Magnesite 3.0) }\end{array}$ & 2.715 \\
\hline Anorthite & 2.76 \\
\hline Polyhalite $\left(\mathrm{K}_{2} \mathrm{MgCa}_{2}\left(\mathrm{SO}_{4}\right)_{4} \cdot 2 \mathrm{H}_{2} \mathrm{O}\right)$ & 2.78 \\
\hline Dolomite & 2.87 \\
\hline Pyroxenes & $2.8-3.7$ \\
\hline Amphibole & $2.9-3.55$ \\
\hline Anhydrite & 2.94 \\
\hline Aragonite & 2.94 \\
\hline Boracite* & 2.95 \\
\hline Rhodochrosite & 3.68 \\
\hline Siderite & 3.95 \\
\hline Sphalerite & $3.9-4.1$ \\
\hline Rutile & 4.2 \\
\hline Goethite (crystalline) & 4.28 \\
\hline Ilmenite & 4.65 \\
\hline Pyrite & 5.0 \\
\hline Hematite & 5.2 \\
\hline Arsenopyrite & $5.5-6$ \\
\hline
\end{tabular}

Note: Above values are of minerals noted or possible in Leg 23 cores. An asterisk indicates minerals not actually observed or inferred.

can be relied on only when corroborated by other methods, why not stick to those methods?

A second argument recognizes sources of error, but points out that these can be reduced by carefully excluding sections based on a study of core photographs and by introducing special calibrations or corrections. The problem here appears to be lack of workers with sufficient interest or knowledge to undertake this type of remedial work. One might suggest that the time could be better spent in getting water content determinations, backed up by adequate numbers of grain density measurements.

The most serious argument against GRAPE for routine sediment measurement is that if it introduces erroneous or misleading data into the Initial Reports volume to any consistent degree, this negative fact far outweighs any benefits it may yield, for in the absence of systematic tests for validity all the porosity measurements from the DSDP are rendered suspect.

2. A new use for GRAPE that might obviate many of the current objections may be to make direct measurements (no linear) on calipered samples of hard rocks (Boyce, oral communication, 1973). As DSDP explores deeper metamorphic, consolidated sedimentary or igneous rocks, such measurements might well yield superior porosity and density data on difficult materials.

3. The water content and other derived parameters from the Red Sea show that consolidation and cementation does not proceed smoothly with depth. Hard-cemented layers and relatively unconsolidated materials occur at nearly all depths. Similar irregular porosities with depth in piston cores were also found in careful studies from the Chain 100 cruise to the Red Sea. These relationships also hold below brick-hard anhydrites and rock salt layers: shales cut off from further water loss by almost totally impermeable rock salt may retain abnormal amounts of pore fluid with respect to their burial depth.

4. A rather pronounced gradation to lower porosities is found in shaly carbonate strata immediately above the evaporite suite. This may be due to diffusion of dissolved components from the evaporites $\left(\mathrm{Mg}, \mathrm{Ca}, \mathrm{SO}_{4}, \mathrm{~K}\right)$ and reprecipitation or diagenetic uptake in the overlying sediments.

\section{RECOMMENDATIONS ${ }^{2}$}

1. Syringe volume and GRAPE determinations of porosity should be discontinued for unconsolidated or semiconsolidated sediments.

2. Increased attention should be given to water content measurements by oven heating. Cutoff syringes may still be useful to obtain samples for this purpose where sediments are sufficiently unconsolidated. Sediments should not be sampled at rigid intervals, but rather by approximate intervals, the exact site to be determined by changing lithologies and availability of undisturbed samples. A coding system designating each water content sample as being from undisturbed or relatively undisturbed strata, partly or questionably disturbed strata, and badly disturbed strata should greatly increase the utility and usability of the data for geological and geophysical purposes.

3 . Routine grain density service should be available at Scripps to categorize chief lithologies for the purpose of converting water content to porosity and density values where assumed values may be questionable.

4. GRAPE equipment might be retained onboard, if space is not at a premium, to be employed on selected consolidated materials where the appropriate conditions for valid measurement could be assured.

\footnotetext{
${ }^{2}$ Note: These recomendations are restricted to the fundamental properties-water content, porosity, and bulk (grain) density-and are not intended to imply the undesirability of other physical or geophy sical measurements.
} 
TABLE 3

Comparative Determination of (Leg 4) Water Content on Syringe and Small Shipboard Samples and on Larger (5-10-g) Samples Sealed and Shipped to Shore Laboratory

\begin{tabular}{|c|c|c|}
\hline Hole, Core, Section & $\begin{array}{c}\text { Mini Samples } \\
\text { (Shipboard Determinations) }\end{array}$ & $\begin{array}{c}\text { Shore Determinations } \\
\text { (5-10-g Samples) }\end{array}$ \\
\hline $23-1-1$ & 49 & 48.9 \\
\hline $23-3-2$ & 34 & 39.7 \\
\hline $23-3-3$ & 41 & - \\
\hline $23-4-1$ & 42 & - \\
\hline $23-4-3(12)$ & 41 & 39.5 \\
\hline $23-4-3(11)$ & 40 & - \\
\hline $24-1-1$ & 12.4 & 8.8 \\
\hline $24-4-3$ & 31.1 & 30.9 \\
\hline $26-1-3$ & $26.6^{\mathrm{a}}$ & \\
\hline & 29.8 & 31.6 \\
\hline $\begin{array}{l}26-3-2 \\
26-5-3\end{array}$ & 23.3 & 26.1 \\
\hline $26-5-3$ & 22.3 & 22.3 \\
\hline $27-1-1$ & 34 & - \\
\hline $27-1-2$ & 38.7 & - \\
\hline $27-1-6$ & 41.6 & - \\
\hline $27-2-1$ & 39.4 & - \\
\hline $27-2-2$ & 33.4 & - \\
\hline $27-2-3$ & 40.5 & 36.9 \\
\hline $27-3-1$ & 22.2 & - \\
\hline $27-3-2$ & 30.0 & 30.8 \\
\hline $27-4-1$ & 27.1 & 28.4 \\
\hline $27-5-1$ & 26.4 & - \\
\hline $27-5-2$ & 27.4 & 25.3 \\
\hline $27 \mathrm{~A}-1-5$ & 42.3 & 42.7 \\
\hline $27 \mathrm{~A}-2-3$ & $38 / 26^{\mathrm{a}}$ & 37.2 \\
\hline $27 \mathrm{~A}-3-3$ & 35 & 37.5 \\
\hline $27 A-4-3$ & 34 & 37.2 \\
\hline $27 \mathrm{~A}-4-3$ & & 27.9 \\
\hline $29-1-3$ & 41 & 34.2 \\
\hline $29-4-3$ & - & 39.0 \\
\hline $29-9-2$ & 64 & 61.7 \\
\hline $29-12-6$ & - & 67.8 \\
\hline $29-14-3$ & 68 & 66.5 \\
\hline $29-17-1$ & 66 & 67.2 \\
\hline $30-2-4$ & 39 & 41.9 \\
\hline $30-3-3$ & 38 & 35.7 \\
\hline $30-6-2$ & 29 & 31.4 \\
\hline $30-11-2$ & 28 & 30.8 \\
\hline $30-13-1$ & 31 & 33.7 \\
\hline $30-15-4(419 \mathrm{~m})$ & 31 & 33.5 \\
\hline
\end{tabular}

Note: From Sayles et al. unpublished data, 1970; Manheim unpublished memorandum, 1970. Values in percent bulk sediment.

${ }^{\mathrm{a}}$ Different lithologic types.

\section{ACKNOWLEDGMENTS}

We thank J. C. Hathaway for his assistance and discussion of the statistical problems.

\section{REFERENCES}

Bennett, R. H. and Keller, G. H., 1973. Physical properties evaluation. In van Andel, T. H., Heath, G. R., et al., Initial Reports of the Deep Sea Drilling Project Volume 16: Washington (U. S. Government Printing Office), p. 513.

Boyce, R. E., 1972. Unpublished memorandum, Scripps Institution of Oceanography, La Jolla, California. , in press. Physical properties-Methods. In Heezen, B. C., MacGregor, I. G.,et al., Initial Reports of the Deep
Sea Drilling Project, Volume 20: Washington (U. S. Government printing office). Appendix (Leg 15 results) I, p. 205-217.

Gealy, E. L., 1971. Saturated bulk density, grain density and porosity of sediment cores from the western equatorial Pacific: Leg 7, Glomar Challenger. In Winterer, E. L. et al., Initial Reports of the Deep Sea Drilling Project, Volume 7: Washington (U. S. Government Printing Office), p. 1081.

Gealy, E. L. and Gerard, R. D., 1970. In situ petrophysical measurements in the Caribbean. In Bader R. G. et al., Initial Reports of the Deep Sea Drilling Project, Volume 4: Washington (U. S. Government Printing Office), p. 167.

Horne, R. A., 1966. Marine chemistry: New York (Wiley, Interscience), $568 \mathrm{p}$. 
TABLE 4

Comparison of Physical Properties for Site 225

\begin{tabular}{|c|c|c|c|c|c|c|}
\hline $\begin{array}{l}\text { Core, Section, } \\
\text { Interval }(\mathrm{cm})\end{array}$ & $\begin{array}{l}\text { Estimated } \\
\text { Depth }(\mathrm{m})\end{array}$ & $\begin{array}{c}\mathrm{H}_{2} \mathrm{O}(\%) \\
\text { (Lab.) }\end{array}$ & $\begin{array}{l}\text { Por } \\
\text { (Lab.) }\end{array}$ & $\begin{array}{l}\text { ity (\%) } \\
\text { (GRAPE) }\end{array}$ & $\begin{array}{l}\text { Density } \\
\left(\mathrm{g} / \mathrm{cm}^{3}\right) \\
\text { (Lab.) }\end{array}$ & $\begin{array}{c}\text { Grain } \\
\text { Density } \\
\left(\mathrm{g} / \mathrm{cm}^{3}\right)\end{array}$ \\
\hline $\begin{array}{l}1-1,128 \\
1-2,42 \\
1-5,45 \\
1-6,10\end{array}$ & $\begin{array}{l}1 \\
2 \\
8 \\
9\end{array}$ & $\begin{array}{l}36.9 \\
34.6 \\
34.9 \\
35.3\end{array}$ & $\begin{array}{l}77.7 \\
73.5 \\
73.2 \\
76.6\end{array}$ & $\begin{array}{l}62.6 \\
60.2 \\
60.6 \\
61.0\end{array}$ & $\begin{array}{l}1.67 \\
1.71 \\
1.70 \\
1.69\end{array}$ & $\begin{array}{l}2.73 \\
2.73 \\
2.73 \\
2.73\end{array}$ \\
\hline $\begin{array}{l}3-1 \\
3-2 \\
3-3 \\
3-4 \\
3-4\end{array}$ & $\begin{array}{l}19 \\
20 \\
22 \\
21 \\
22\end{array}$ & $\begin{array}{l}28.3 \\
25.4 \\
25.2 \\
26.3 \\
27.1\end{array}$ & $\begin{array}{c}55.0 \\
50.2 \\
- \\
-\end{array}$ & $\begin{array}{l}52.9 \\
49.1 \\
48.8 \\
50.3 \\
51.2\end{array}$ & $\begin{array}{l}1.83 \\
1.89 \\
1.90 \\
1.87 \\
1.85\end{array}$ & $\begin{array}{l}2.73 \\
2.73 \\
2.72 \\
2.71 \\
2.71\end{array}$ \\
\hline $\begin{array}{l}4-1 \\
4-2 \\
4-3 \\
4-4 \\
4-5,85 \\
4-5,108 \\
4-6\end{array}$ & $\begin{array}{l}23 \\
23 \\
24 \\
25 \\
26 \\
27 \\
27\end{array}$ & $\begin{array}{l}34.5 \\
28.3 \\
37.9 \\
38.1 \\
55.1 \\
35.0 \\
40.0\end{array}$ & $\begin{array}{c}- \\
- \\
- \\
- \\
71.6 \\
46.5 \\
-\end{array}$ & $\begin{array}{l}60.0 \\
52.8 \\
63.5 \\
63.7 \\
78.4 \\
60.4 \\
65.5\end{array}$ & $\begin{array}{l}1.70 \\
1.83 \\
1.64 \\
1.64 \\
1.39 \\
1.69 \\
1.61\end{array}$ & $\begin{array}{l}2.71 \\
2.71 \\
2.70 \\
2.70 \\
2.70 \\
2.69 \\
2.69\end{array}$ \\
\hline $\begin{array}{l}5-3,80 \\
5-4,145 \\
5-5,140 \\
5-6 \\
5-6\end{array}$ & $\begin{array}{l}30 \\
32 \\
33 \\
35 \\
36\end{array}$ & $\begin{array}{c}29.8 \\
(44.6 ?) \\
37.8 \\
39.7 \\
40.3 \\
40.9 \\
27.8\end{array}$ & $\begin{array}{c}- \\
49.1 \\
50.5 \\
52.1 \\
- \\
54.1\end{array}$ & $\begin{array}{c}54.5 \\
(69.9 ?) \\
63.5 \\
65.5 \\
66.1 \\
66.7 \\
52.3\end{array}$ & $\begin{array}{c}1.79 \\
(1.54 ?) \\
1.64 \\
1.61 \\
1.61 \\
1.60 \\
1.84\end{array}$ & $\begin{array}{l}2.70 \\
\\
2.70 \\
2.71 \\
2.72 \\
2.72 \\
2.73\end{array}$ \\
\hline $\begin{array}{l}6-1,73 \\
6-5,123 \\
6-6,113\end{array}$ & $\begin{array}{l}37 \\
42 \\
44\end{array}$ & $\begin{array}{l}34.8 \\
35.6 \\
39.8\end{array}$ & $\begin{array}{l}53.6 \\
52.4 \\
55.3\end{array}$ & $\begin{array}{l}60.7 \\
61.6 \\
65.9\end{array}$ & $\begin{array}{l}1.71 \\
1.69 \\
1.62\end{array}$ & $\begin{array}{l}2.74 \\
2.74 \\
2.75\end{array}$ \\
\hline $8-3,80$ & 48 & 36.4 & 60.6 & 62.6 & 1.68 & 2.76 \\
\hline $\begin{array}{l}9-3 \\
9-4,35 \\
9-5,70 \\
9-6,60\end{array}$ & $\begin{array}{l}48 \\
50 \\
51 \\
54\end{array}$ & $\begin{array}{l}25.5 \\
29.5 \\
40.7 \\
25.8\end{array}$ & $\begin{array}{l}(58.8) \\
52.5 \\
67.8 \\
47.6\end{array}$ & $\begin{array}{l}49.6 \\
54.8 \\
66.9 \\
50.0\end{array}$ & $\begin{array}{l}1.91 \\
1.82 \\
1.61 \\
1.90\end{array}$ & $\begin{array}{l}2.76 \\
2.76 \\
2.76 \\
2.76\end{array}$ \\
\hline $10-2,90$ & 57 & 27.8 & 54.5 & 52.6 & 1.85 & 2.75 \\
\hline $11-4$ & 75 & 24.0 & $(62.1)$ & 47.5 & 1.94 & 2.75 \\
\hline $12-1,110$ & 77 & 41.5 & 64.7 & 67.7 & 1.59 & 2.75 \\
\hline $\begin{array}{l}13-4,23 \\
13-4,70 \\
13-4,120 \\
13-6,50\end{array}$ & $\begin{array}{l}81 \\
82 \\
84 \\
86\end{array}$ & $\begin{array}{l}38.7 \\
41.8 \\
41.8 \\
25.0\end{array}$ & $\begin{array}{l}\overline{-} \\
\overline{-} \\
65.7\end{array}$ & $\begin{array}{l}65.0 \\
67.9 \\
68.0 \\
48.9\end{array}$ & $\begin{array}{l}1.64 \\
1.59 \\
1.59 \\
1.91\end{array}$ & $\begin{array}{l}2.75 \\
2.74 \\
2.74 \\
2.74\end{array}$ \\
\hline $\begin{array}{l}14-1,100 \\
14-1,112 \\
14-2,127 \\
14-4,10 \\
14-4\end{array}$ & $\begin{array}{l}87 \\
88 \\
90 \\
93 \\
94\end{array}$ & $\begin{array}{l}10.3 \\
28.3 \\
33.1 \\
33.7 \\
31.8\end{array}$ & $\begin{array}{c}48.8 \\
53.0 \\
70.1 \\
59.6 \\
-\end{array}$ & $\begin{array}{l}24.6 \\
53.2 \\
58.9 \\
59.6 \\
57.5\end{array}$ & $\begin{array}{l}2.32 \\
1.83 \\
1.74 \\
1.72 \\
1.76\end{array}$ & $\begin{array}{l}2.74 \\
2.73 \\
2.73 \\
2.73 \\
2.73\end{array}$ \\
\hline $15-2,82$ & 97 & 23.0 & 59.7 & 46.0 & 1.95 & 2.72 \\
\hline $\begin{array}{l}16-2,80 \\
16-3\end{array}$ & $\begin{array}{l}106 \\
108\end{array}$ & $\begin{array}{l}12.8 \\
20.4\end{array}$ & $\begin{array}{c}56.8 \\
(40.9)\end{array}$ & $\begin{array}{l}29.3 \\
42.2\end{array}$ & $\begin{array}{l}2.23 \\
2.01\end{array}$ & $\begin{array}{l}2.72 \\
2.72\end{array}$ \\
\hline $\begin{array}{l}17-2,40 \\
17-3,50 \\
17-4,130\end{array}$ & $\begin{array}{l}115 \\
117 \\
120\end{array}$ & $\begin{array}{l}13.3 \\
25.1 \\
12.9\end{array}$ & $\begin{array}{l}49.1 \\
51.4 \\
47.6\end{array}$ & $\begin{array}{l}30.3 \\
49.1 \\
29.7\end{array}$ & $\begin{array}{l}2.22 \\
1.90 \\
2.24\end{array}$ & $\begin{array}{l}2.73 \\
2.73 \\
2.74\end{array}$ \\
\hline $\begin{array}{l}18-1,60 \\
18-2,20\end{array}$ & $\begin{array}{l}123 \\
127\end{array}$ & $\begin{array}{l}17.3 \\
25.1\end{array}$ & $\begin{array}{c}51.6 \\
-\end{array}$ & $\begin{array}{l}37.6 \\
49.4\end{array}$ & $\begin{array}{l}2.11 \\
1.91\end{array}$ & $\begin{array}{l}2.75 \\
2.75\end{array}$ \\
\hline $\begin{array}{l}19-1,137 \\
19-4,23\end{array}$ & $\begin{array}{l}133 \\
138\end{array}$ & $\begin{array}{l}35.3 \\
35.8\end{array}$ & $\begin{array}{l}53.0 \\
63.1\end{array}$ & $\begin{array}{l}62.1 \\
63.0\end{array}$ & $\begin{array}{l}1.70 \\
1.70\end{array}$ & $\begin{array}{l}2.76 \\
2.78\end{array}$ \\
\hline $20-1,35$ & 142 & 44.3 & - & 71.7 & 1.56 & 2.80 \\
\hline $21-3,10$ & 153 & 35.1 & - & 63.1 & 1.72 & 2.81 \\
\hline $22-5,50$ & 165 & 25.4 & 56.3 & 52.3 & 1.94 & 2.85 \\
\hline $23-1,139$ & 170 & 15.1 & 33.9 & 36.4 & 2.25 & 2.85 \\
\hline $\begin{array}{l}24-1 \\
24-1,150\end{array}$ & $\begin{array}{l}179 \\
180\end{array}$ & $\begin{array}{l}3.6 \\
4.1\end{array}$ & $\begin{array}{c}15.5 \\
-\end{array}$ & $\begin{array}{l}10.7 \\
12.0\end{array}$ & $\begin{array}{l}2.75 \\
2.71\end{array}$ & $\begin{array}{l}2.94 \\
2.92\end{array}$ \\
\hline
\end{tabular}


TABLE 4 - Continued

\begin{tabular}{|c|c|c|c|c|c|c|}
\hline $\begin{array}{l}\text { Core, Section, } \\
\text { Interval }(\mathrm{cm})\end{array}$ & $\begin{array}{l}\text { Estimated } \\
\text { Depth (m) }\end{array}$ & $\begin{array}{c}\mathrm{H}_{2} \mathrm{O}(\%) \\
\text { (Lab.) }\end{array}$ & \multicolumn{2}{|c|}{ Porosity (\%) } & $\begin{array}{c}\text { Density } \\
\left(\mathrm{g} / \mathrm{cm}^{3}\right) \\
(\mathrm{Lab} .)\end{array}$ & $\begin{array}{c}\text { Grain } \\
\text { Density } \\
\left(\mathrm{g} / \mathrm{cm}^{3}\right)\end{array}$ \\
\hline $\begin{array}{l}26-1 \\
26-1,25\end{array}$ & $\begin{array}{l}198 \\
199\end{array}$ & $\begin{array}{l}<1.0^{\mathrm{a}} \\
20.7^{\mathrm{b}}\end{array}$ & - & $\begin{array}{l}<3.0 \\
46.4\end{array}$ & $\begin{array}{l}2.88 \\
2.01\end{array}$ & $\begin{array}{l}2.94 \\
2.74\end{array}$ \\
\hline $\begin{array}{l}27-1 \\
27-1 \\
27-2,75\end{array}$ & $\begin{array}{l}206 \\
208 \\
209\end{array}$ & $\begin{array}{l}1.26^{\mathrm{a}} \\
0.56^{\mathrm{c}} \\
9.16^{\mathrm{a}}\end{array}$ & $\begin{array}{c}- \\
\overline{19.8}\end{array}$ & $\begin{array}{r}3.8 \\
1.7 \\
24.9\end{array}$ & $\begin{array}{l}2.86 \\
2.2 \\
2.44\end{array}$ & $\begin{array}{l}2.93 \\
2.2 \\
2.86\end{array}$ \\
\hline 29. & 225 & $0.5^{3}$ & - & 1.2 & 2.2 & 2.2 \\
\hline
\end{tabular}

Note: $\mathrm{H}_{2} \mathrm{O}$ (Lab.) refers to shipboard water content values obtained by oven drying at $110^{\circ}$ $120^{\circ} \mathrm{C}$. Porosity (Lab.) and Density (Lab.) utilize $\mathrm{H}_{2} \mathrm{O}$ values and grain density values according to equations (6) and (7). Porosity (GRAPE) refers to values from gamma attenuation measurements on cores with liners. Values are taken from GRAPE log printout by taking the mean of samples $2 \mathrm{~cm}$ on either side of the measured position of the water content samples. Grain densities as determined in Table 1 are extended or interpolated to intervening lithologies according to shipboard and other laboratorydetermined logs. Parentheses denote alternate lithology sampled at interval.

${ }^{a}$ Dense anhydrite.

$\mathrm{b}_{\text {Shale. }}$

${ }^{\mathrm{c}}$ Halite rock. 
TABLE 5

Comparison of Physical Properties for Site 227

\begin{tabular}{|c|c|c|c|c|c|c|}
\hline \multirow{2}{*}{$\begin{array}{l}\text { Core, Section, } \\
\text { Interval }(\mathrm{cm})\end{array}$} & \multirow{2}{*}{$\begin{array}{l}\text { Estimated } \\
\text { Depth }(\mathrm{m})\end{array}$} & \multirow{2}{*}{$\begin{array}{c}\mathrm{H}_{2} \mathrm{O}(\%) \\
\text { (Lab.) }\end{array}$} & \multicolumn{2}{|c|}{ Porosity $(\%)$} & \multirow{2}{*}{$\begin{array}{c}\text { Density } \\
\left(\mathrm{g} / \mathrm{cm}^{3}\right) \\
(\mathrm{Lab} .)\end{array}$} & \multirow{2}{*}{$\begin{array}{c}\text { Grain } \\
\text { Density } \\
\left(\mathrm{g} / \mathrm{cm}^{3}\right)\end{array}$} \\
\hline & & & & & & \\
\hline $\begin{array}{l}3-1,16 \\
3-1,148\end{array}$ & $\begin{array}{l}2 \\
3\end{array}$ & $\begin{array}{l}35.6 \\
21.1\end{array}$ & $\begin{array}{l}60.2 \\
42.1\end{array}$ & $\begin{array}{l}63.1 \\
44.5\end{array}$ & $\begin{array}{l}1.66 \\
1.96\end{array}$ & $\begin{array}{l}2.61 \\
2.63\end{array}$ \\
\hline $\begin{array}{l}5-1,115 \\
5-2,50\end{array}$ & $\begin{array}{l}37 \\
38\end{array}$ & $\begin{array}{l}21.9 \\
28.7\end{array}$ & $\begin{array}{l}43.7 \\
53.1\end{array}$ & 65.8 & $\begin{array}{l}1.95 \\
1.81\end{array}$ & $\begin{array}{l}2.66 \\
2.68\end{array}$ \\
\hline $\begin{array}{l}6-1,68 \\
6-1,78 \\
6-2,88\end{array}$ & $\begin{array}{l}46 \\
46 \\
48\end{array}$ & $\begin{array}{l}22.5 \\
29.0 \\
17.8\end{array}$ & $\begin{array}{l}45.1 \\
54.0 \\
38.3\end{array}$ & $\begin{array}{l}45.8 \\
62.6 \\
51.5\end{array}$ & $\begin{array}{l}1.96 \\
1.82 \\
2.10\end{array}$ & $\begin{array}{l}2.71 \\
2.73 \\
2.75\end{array}$ \\
\hline $8-1,120$ & 65 & 20.6 & 42.7 & - & 2.02 & 2.75 \\
\hline $10-2,145$ & 76 & 21.2 & 43.6 & 52.7 & 2.01 & 2.75 \\
\hline $\begin{array}{l}12-1,140 \\
12-2,91\end{array}$ & $\begin{array}{l}82 \\
84\end{array}$ & $\begin{array}{l}23.2 \\
18.7\end{array}$ & $\begin{array}{l}46.9 \\
40.2\end{array}$ & - & $\begin{array}{l}1.96 \\
2.08\end{array}$ & $\begin{array}{l}2.76 \\
2.76\end{array}$ \\
\hline $13-1,25$ & 91 & 24.2 & 48.8 & 75.2 & 1.94 & 2.76 \\
\hline $14-1,78$ & 101 & 21.7 & 45.4 & - & 2.00 & 2.76 \\
\hline $15-1,101$ & 109 & 25.6 & 51.3 & - & 1.91 & 2.77 \\
\hline $\begin{array}{l}16-1,104 \\
16-2,30\end{array}$ & $\begin{array}{l}114 \\
115\end{array}$ & $\begin{array}{l}15.1 \\
18.0\end{array}$ & $\begin{array}{l}34.9 \\
40.1\end{array}$ & $\begin{array}{l}36.3 \\
54.8\end{array}$ & $\begin{array}{l}2.19 \\
2.10\end{array}$ & $\begin{array}{l}2.77 \\
2.77\end{array}$ \\
\hline $\begin{array}{l}17-1,110 \\
17-2,143\end{array}$ & $\begin{array}{l}123 \\
125\end{array}$ & $\begin{array}{l}19.2 \\
23.2\end{array}$ & $\begin{array}{l}42.7 \\
49.1\end{array}$ & $\begin{array}{l}68.6 \\
62.4\end{array}$ & $\begin{array}{l}2.07 \\
1.97\end{array}$ & $\begin{array}{l}2.78 \\
2.78\end{array}$ \\
\hline $\begin{array}{l}18-1,130 \\
18-2,128 \\
18-3,40\end{array}$ & $\begin{array}{l}132 \\
134 \\
135\end{array}$ & $\begin{array}{l}20.3 \\
19.4 \\
17.5\end{array}$ & $\begin{array}{l}45.0 \\
43.6 \\
40.5\end{array}$ & $\begin{array}{l}42.3 \\
66.6 \\
42.0\end{array}$ & $\begin{array}{l}2.04 \\
2.07 \\
2.12\end{array}$ & $\begin{array}{l}2.78 \\
2.78 \\
2.79\end{array}$ \\
\hline $\begin{array}{l}19-1,95 \\
19-3,45 \\
19-3,15\end{array}$ & $\begin{array}{l}141 \\
143 \\
143\end{array}$ & $\begin{array}{l}23.3 \\
21.4 \\
18.4\end{array}$ & $\begin{array}{l}50.2 \\
47.3 \\
42.3\end{array}$ & $\begin{array}{l}67.8 \\
49.7 \\
56.1\end{array}$ & $\begin{array}{l}1.97 \\
2.02 \\
2.10\end{array}$ & $\begin{array}{l}2.79 \\
2.79 \\
2.79\end{array}$ \\
\hline $\begin{array}{l}20-2,80 \\
20-3,100 \\
20-4,80 \\
20-5,85\end{array}$ & $\begin{array}{l}150 \\
153 \\
155 \\
156\end{array}$ & $\begin{array}{l}25.3 \\
14.8 \\
18.2 \\
16.4\end{array}$ & $\begin{array}{l}53.5 \\
36.1 \\
42.4 \\
39.2\end{array}$ & $\begin{array}{l}60.4 \\
49.5 \\
42.8 \\
42.5\end{array}$ & $\begin{array}{l}1.92 \\
2.21 \\
2.11 \\
2.16\end{array}$ & $\begin{array}{l}2.79 \\
2.80 \\
2.80 \\
2.80\end{array}$ \\
\hline $\begin{array}{l}22-2,90 \\
22-3 \\
22-4,68\end{array}$ & $\begin{array}{l}160 \\
162 \\
172\end{array}$ & $\begin{array}{l}25.1 \\
21.1 \\
19.9\end{array}$ & $\begin{array}{l}53.7 \\
47.6 \\
46.1\end{array}$ & $\begin{array}{r}50.7 \\
- \\
42.5\end{array}$ & $\begin{array}{l}1.93 \\
2.03 \\
2.06\end{array}$ & $\begin{array}{l}2.80 \\
2.80 \\
2.80\end{array}$ \\
\hline $24-6,51$ & 185 & 17.8 & 42.9 & 44.3 & 2.12 & 2.80 \\
\hline $25-2,39$ & 187 & 18.7 & 44.6 & 50.9 & 2.09 & 2.80 \\
\hline $26-2,115$ & 197 & 17.3 & 42.2 & - & 2.14 & 2.80 \\
\hline $27-1,40$ & 203 & 10.0 & 27.1 & - & 2.37 & 2.79 \\
\hline $\begin{array}{l}28-1,135 \\
28-2,46 \\
28-3,35\end{array}$ & $\begin{array}{l}213 \\
214 \\
215\end{array}$ & $\begin{array}{l}17.8 \\
17.8 \\
19.1\end{array}$ & $\begin{array}{l}43.3 \\
43.5 \\
46.0\end{array}$ & $\begin{array}{c}- \\
52.6 \\
64.9\end{array}$ & $\begin{array}{l}2.13 \\
2.13 \\
2.11\end{array}$ & $\begin{array}{l}2.81 \\
2.83 \\
2.85\end{array}$ \\
\hline $30-1,130$ & 228 & $1.0^{\mathrm{a}}$ & 3.2 & - & 2.83 & 2.88 \\
\hline $\begin{array}{l}32-3 \\
32-5,83\end{array}$ & $\begin{array}{l}248 \\
252\end{array}$ & $\begin{array}{l}0.2 \\
0.2\end{array}$ & $\begin{array}{l}0.6 \\
0.6\end{array}$ & $\begin{array}{l}- \\
-\end{array}$ & $\begin{array}{l}2.2 \\
2.2\end{array}$ & $\begin{array}{l}2.2 \\
2.2\end{array}$ \\
\hline $\begin{array}{l}36-2,46-53 \\
36-2,106\end{array}$ & $\begin{array}{l}282 \\
283\end{array}$ & $\begin{array}{c}2.43^{\mathrm{a}} \\
22.4^{\mathrm{b}}\end{array}$ & $\begin{array}{r}6.6 \\
49.3\end{array}$ & - & $\begin{array}{l}2.78 \\
1.91\end{array}$ & $\begin{array}{l}2.93 \\
2.43\end{array}$ \\
\hline $44, \mathrm{CC}$ & 350 & $14.0^{\mathrm{b}}$ & 35.0 & - & 2.16 & 2.67 \\
\hline
\end{tabular}

Note: See Table 4 for detailed explanations.

${ }^{a}$ Dense anhydrite.

${ }^{\mathrm{b}}$ Shale, cristobalitic. 
TABLE 6

Comparison of Physical Properties for Site 228

\begin{tabular}{|c|c|c|c|c|c|c|}
\hline $\begin{array}{l}\text { Core, Section, } \\
\text { Interval }(\mathrm{cm})\end{array}$ & $\begin{array}{l}\text { Estimated } \\
\text { Depth (m) }\end{array}$ & $\begin{array}{c}\mathrm{H}_{2} \mathrm{O}(\%) \\
\text { (Lab.) }\end{array}$ & $\begin{array}{l}\text { Porc } \\
\text { (Lab.) }\end{array}$ & $\begin{array}{l}\text { ty }(\%) \\
\text { (GRAPE) }\end{array}$ & $\begin{array}{l}\text { Density } \\
\left(\mathrm{g} / \mathrm{cm}^{3}\right) \\
(\mathrm{Lab} .)\end{array}$ & $\begin{array}{c}\text { Grain } \\
\text { Density } \\
\left(\mathrm{g} / \mathrm{cm}^{3}\right)\end{array}$ \\
\hline $1-2,82$ & 2.32 & 28.2 & $\begin{array}{c}54.8 \\
(53.0)\end{array}$ & & $\begin{array}{c}1.94 \\
(1.84)\end{array}$ & 2.75 \\
\hline $1-4,57$ & 5.07 & 32.0 & 57.7 & & 1.76 & 2.75 \\
\hline $\begin{array}{l}2-1,68 \\
2-2,50 \\
2-3,40\end{array}$ & $\begin{array}{l}15.6 \\
17.0 \\
18.4\end{array}$ & $\begin{array}{l}24.8 \\
25.3 \\
26.1\end{array}$ & $\begin{array}{l}48.1 \\
49.5 \\
50.6\end{array}$ & $\begin{array}{l}44.6 \\
49.6\end{array}$ & $\begin{array}{l}1.93 \\
1.91 \\
1.89\end{array}$ & $\begin{array}{l}2.75 \\
2.75 \\
2.75\end{array}$ \\
\hline $3-1,45$ & 24.4 & 25.9 & 50.4 & 66.7 & 1.89 & 2.75 \\
\hline $\begin{array}{l}4-1,40 \\
4-2,40 \\
4-3,100\end{array}$ & $\begin{array}{l}24.4 \\
25.9 \\
28.0\end{array}$ & $\begin{array}{l}37.4 \\
26.1 \\
31.8\end{array}$ & $\begin{array}{c}63.9 \\
50.7 \\
61.7 \\
(57.8)\end{array}$ & $\begin{array}{l}62.8 \\
48.2 \\
53.9\end{array}$ & $\begin{array}{c}1.66 \\
1.89 \\
1.94 \\
(1.77)\end{array}$ & $\begin{array}{l}2.75 \\
2.75 \\
2.75\end{array}$ \\
\hline $\begin{array}{l}4-4,103 \\
4-5,80\end{array}$ & $\begin{array}{l}29.5 \\
30.8\end{array}$ & $\begin{array}{l}37.2 \\
29.8\end{array}$ & $\begin{array}{l}63.8 \\
55.5\end{array}$ & $\begin{array}{l}59.6 \\
48.9\end{array}$ & $\begin{array}{l}1.67 \\
1.81\end{array}$ & $\begin{array}{l}2.75 \\
2.75\end{array}$ \\
\hline $5-3,95$ & 36.9 & 30.3 & $\begin{array}{c}58.7 \\
(56.2)\end{array}$ & 55.9 & $\begin{array}{c}1.91 \\
(1.80)\end{array}$ & 2.75 \\
\hline $5-4,123$ & 38.7 & 24.0 & $\begin{array}{c}53.3 \\
(48.0)\end{array}$ & 46.0 & $\begin{array}{c}2.22 \\
(1.74)\end{array}$ & 2.75 \\
\hline $\begin{array}{l}6-2,80 \\
6-3,140\end{array}$ & $\begin{array}{l}44.3 \\
46.4\end{array}$ & $\begin{array}{l}27.1 \\
36.2\end{array}$ & $\begin{array}{c}52.3 \\
73.4 \\
(63.1)\end{array}$ & $\begin{array}{l}49.7 \\
58.9\end{array}$ & $\begin{array}{c}1.87 \\
2.03 \\
(1.68)\end{array}$ & $\begin{array}{l}2.75 \\
2.75\end{array}$ \\
\hline $6-4,70$ & 47.2 & 30.4 & $\begin{array}{c}65.6 \\
(56.5)\end{array}$ & 51.6 & $\begin{array}{c}2.16 \\
(1.80)\end{array}$ & 2.75 \\
\hline $6-5,110$ & 49.1 & 24.4 & $\begin{array}{c}49.7 \\
(48.7)\end{array}$ & 43.4 & $\begin{array}{c}2.04 \\
(1.93)\end{array}$ & 2.75 \\
\hline $6-6,50$ & 50.0 & 22.6 & $\begin{array}{c}47.6 \\
(46.2)\end{array}$ & 42.8 & $\begin{array}{c}2.10 \\
(1.97)\end{array}$ & 2.75 \\
\hline $7-1,40$ & 51.4 & 24.7 & $\begin{array}{c}56.3 \\
(49.2)\end{array}$ & 49.7 & $\begin{array}{c}2.22 \\
(1.92)\end{array}$ & 2.75 \\
\hline $7-2,58$ & 53.0 & 35.9 & 63.0 & 47.4 & 1.69 & 2.75 \\
\hline $7-4,74$ & 56.2 & 29.8 & 56.0 & 49.3 & 1.81 & 2.75 \\
\hline $7-5,100$ & 58.0 & 26.4 & 51.7 & 47.4 & 1.88 & 2.75 \\
\hline $7-6,40$ & 58.9 & 23.3 & $\begin{array}{c}48.9 \\
(45.9)\end{array}$ & 39.7 & 2.20 & $\begin{array}{c}2.75 \\
(1.98)\end{array}$ \\
\hline $8-3,75$ & 63.7 & 20.9 & 44.0 & 48.3 & 2.02 & 2.76 \\
\hline $10-6,67$ & 77.1 & 33.4 & $\begin{array}{c}45.5 \\
(47.9)\end{array}$ & 39.0 & $\begin{array}{c}1.95 \\
(1.95)\end{array}$ & 2.76 \\
\hline $11-4,85$ & 83.3 & 20.6 & $\begin{array}{c}44.6 \\
(43.7)\end{array}$ & 39.1 & $\begin{array}{c}2.16 \\
(2.03)\end{array}$ & 2.76 \\
\hline $12-4,135$ & 92.8 & 19.8 & 42.8 & 51.4 & 2.05 & 2.77 \\
\hline $13-2,108$ & 98.5 & 18.6 & 40.9 & 41.6 & 2.08 & 2.77 \\
\hline $\begin{array}{l}14-1,24 \\
14-2,46 \\
14-4,81\end{array}$ & $\begin{array}{l}105.2 \\
106.9 \\
110.3\end{array}$ & $\begin{array}{l}16.6 \\
18.1 \\
19.9\end{array}$ & $\begin{array}{l}37.6 \\
40.1 \\
43.1\end{array}$ & $\begin{array}{l}42.2 \\
41.7 \\
44.7\end{array}$ & $\begin{array}{l}2.14 \\
2.10 \\
2.05\end{array}$ & $\begin{array}{l}2.77 \\
2.77 \\
2.77\end{array}$ \\
\hline $\begin{array}{l}15-1,122 \\
15-2,80 \\
15-4,77\end{array}$ & $\begin{array}{l}115.2 \\
116.3 \\
119.2\end{array}$ & $\begin{array}{l}25.7 \\
21.9 \\
20.5\end{array}$ & $\begin{array}{l}51.8 \\
46.3 \\
44.2\end{array}$ & $\begin{array}{l}49.2 \\
46.2 \\
47.6\end{array}$ & $\begin{array}{l}1.90 \\
2.00 \\
2.03\end{array}$ & $\begin{array}{l}2.77 \\
2.77 \\
2.77\end{array}$ \\
\hline $\begin{array}{l}16-2,12 \\
16-3,22 \\
16-5,78\end{array}$ & $\begin{array}{l}124.6 \\
125.2 \\
129.7\end{array}$ & $\begin{array}{l}14.4 \\
20.1 \\
18.2\end{array}$ & $\begin{array}{l}33.8 \\
43.6 \\
40.5\end{array}$ & $\begin{array}{l}39.0 \\
48.0 \\
40.5\end{array}$ & $\begin{array}{l}2.21 \\
2.04 \\
2.10\end{array}$ & $\begin{array}{l}2.77 \\
2.77 \\
2.77\end{array}$ \\
\hline $18-8,136$ & 142.36 & 14.8 & 34.4 & 66.9 & 2.18 & 2.75 \\
\hline $19-3,51$ & 153.5 & 19.3 & 42.4 & 46.4 & 2.06 & 2.75 \\
\hline $\begin{array}{l}20-1,35 \\
20-2,60 \\
20-3,52\end{array}$ & $\begin{array}{l}155.3 \\
156.5 \\
158.5\end{array}$ & $\begin{array}{l}18.7 \\
21.0 \\
16.9\end{array}$ & $\begin{array}{l}41.5 \\
45.2 \\
36.8\end{array}$ & $\begin{array}{l}76.5 \\
52.5 \\
32.1\end{array}$ & $\begin{array}{l}2.08 \\
2.02 \\
2.17\end{array}$ & $\begin{array}{l}2.76 \\
2.76 \\
2.78\end{array}$ \\
\hline $\begin{array}{l}21-1,50 \\
21-2,60 \\
21-3,20 \\
21-4,51\end{array}$ & $\begin{array}{l}164.5 \\
166.1 \\
167.2 \\
168.5\end{array}$ & $\begin{array}{l}14.8 \\
23.7 \\
16.3 \\
16.8\end{array}$ & $\begin{array}{l}35.0 \\
50.0 \\
38.0 \\
38.9\end{array}$ & $\begin{array}{l}55.9 \\
47.3 \\
35.9 \\
51.6\end{array}$ & $\begin{array}{l}2.21 \\
1.97 \\
2.18 \\
2.16\end{array}$ & $\begin{array}{l}2.80 \\
2.82 \\
2.82 \\
2.82\end{array}$ \\
\hline
\end{tabular}


TABLE 6 - Continued

\begin{tabular}{|c|c|c|c|c|c|c|}
\hline \multirow{2}{*}{$\begin{array}{l}\text { Core, Section, } \\
\text { Interval }(\mathrm{cm})\end{array}$} & \multirow{2}{*}{$\begin{array}{l}\text { Estimated } \\
\text { Depth (m) }\end{array}$} & \multirow{2}{*}{$\begin{array}{c}\mathrm{H}_{2} \mathrm{O}(\%) \\
\text { (Lab.) }\end{array}$} & \multicolumn{2}{|c|}{ Porosity $(\%)$} & \multirow{2}{*}{$\begin{array}{c}\text { Density } \\
\left(\mathrm{g} / \mathrm{cm}^{3}\right) \\
(\mathrm{Lab} .)\end{array}$} & \multirow{2}{*}{$\begin{array}{c}\text { Grain } \\
\text { Density } \\
\left(\mathrm{g} / \mathrm{cm}^{3}\right)\end{array}$} \\
\hline & & & (Lab.) & (GRAPE) & & \\
\hline $23-1,50$ & 182.5 & 11.9 & 29.7 & 52.4 & 2.32 & 2.82 \\
\hline $23-2$ & 183.5 & 21.3 & 47.3 & - & 2.02 & 2.82 \\
\hline $23-3,16$ & 185.1 & 14.7 & 35.2 & 36.0 & 2.22 & 2.82 \\
\hline $24-2,102$ & 143.5 & 21.1 & 46.3 & 47.8 & 2.04 & 2.82 \\
\hline $24-3,28$ & 144.2 & 14.2 & 34.3 & 46.6 & 2.24 & 2.82 \\
\hline $25-1,60$ & 200.6 & 13.7 & 33.3 & - & 2.26 & 2.82 \\
\hline $25-2,4$ & 201.5 & 16.0 & 37.7 & 44.9 & 2.18 & 2.82 \\
\hline $25-4,60$ & 205.1 & 20.6 & 45.5 & 59.0 & 2.05 & 2.81 \\
\hline $26-1,130$ & 210.3 & 17.1 & 39.6 & 54.0 & 2.15 & 2.81 \\
\hline $26-1,130-133$ & 210.3 & 16.2 & 38.0 & - & 2.17 & 2.81 \\
\hline $26-2,16$ & 210.6 & 13.5 & 32.9 & 40.7 & 2.26 & 2.81 \\
\hline $26-4,48$ & 213.9 & 25.4 & 52.8 & 30.9 & 1.93 & 2.81 \\
\hline $27-1,70$ & 218.7 & 13.5 & 32.9 & 45.8 & 2.26 & 2.81 \\
\hline $27-2,55$ & 220.0 & 13.8 & 33.5 & 41.4 & 2.25 & 2.81 \\
\hline $27-3,110$ & 222.1 & 18.1 & 41.4 & 49.7 & 2.12 & 2.81 \\
\hline $28-1,20$ & 227.2 & 16.2 & 38.1 & $(47.6)$ & 2.17 & 2.81 \\
\hline $28-2,101$ & 229.5 & 14.3 & 34.5 & 39.6 & 2.23 & 2.80 \\
\hline $28-4,104$ & 232.5 & 15.6 & 36.9 & 38.9 & 2.19 & 2.80 \\
\hline $29-1,39$ & 236.8 & 13.4 & 32.7 & 45.0 & 2.26 & 2.80 \\
\hline $29-2,35$ & 237.8 & 14.5 & 34.9 & $(70.4)$ & 2.22 & 2.80 \\
\hline $30-1,120$ & 246.2 & 14.6 & 35.1 & 38.5 & 2.22 & 2.80 \\
\hline $30-1,120$ & 246.2 & 13.5 & 32.9 & - & 2.25 & 2.80 \\
\hline $30-4,57$ & 250.0 & 14.1 & 34.1 & 40.1 & 2.23 & 2.80 \\
\hline $30-4,140$ & 250.9 & 11.4 & 28.7 & 34.8 & 2.32 & 2.80 \\
\hline $30-6,28$ & 252.7 & 12.6 & 31.1 & 42.2 & 2.28 & 2.79 \\
\hline $31-3,110$ & 255.10 & 12.5 & 30.9 & 41.1 & 2.28 & 2.79 \\
\hline $31-4,10$ & 258.6 & 15.5 & 36.6 & 36.5 & 2.18 & 2.78 \\
\hline $32-2,8$ & 264.5 & 22.0 & 47.7 & 43.0 & 2.00 & 2.78 \\
\hline $33-2,35$ & 269.8 & 22.4 & 48.3 & 42.5 & 1.99 & 2.78 \\
\hline $33-3,100$ & 272.0 & 3.9 & 11.0 & 24.9 & 2.70 & 2.90 \\
\hline $34-1,70$ & 277.7 & 10.5 & 26.9 & (63.9) & 2.35 & 2.79 \\
\hline $34-3,50$ & 280.5 & 15.1 & 36.2 & 37.7 & 2.20 & 2.79 \\
\hline $35-1,140-150$ & 287.4 & $(0.2)$ & 0.6 & 48.7 & 2.2 & 2.21 \\
\hline $35-1,140-150$ & & 1.4 & 4.2 & - & 2.86 & 2.93 \\
\hline $35-1,140-150$ & & 0.2 & 0.6 & - & 2.2 & 2.2 \\
\hline
\end{tabular}

Note: See Table 4 for detailed explanations.

TABLE 7

Comparison of Physical Properties for Site 229

\begin{tabular}{lcccccc}
\hline $\begin{array}{c}\text { Core, Section, } \\
\text { Interval (cm) }\end{array}$ & $\begin{array}{c}\text { Estimated } \\
\text { Depth }(\mathrm{m})\end{array}$ & $\begin{array}{c}\mathrm{H}_{2} \mathrm{O}(\%) \\
(\mathrm{Lab} .)\end{array}$ & \multicolumn{2}{c}{$\begin{array}{c}\text { Porosity }(\%) \\
(\text { Lab.) }\end{array}$} & $\begin{array}{c}\text { Density } \\
\left(\mathrm{G} / \mathrm{cm}^{3}\right) \\
(\mathrm{Lab})\end{array}$ & $\begin{array}{c}\text { Grain } \\
\text { Density } \\
\left(\mathrm{g} / \mathrm{cm}^{3}\right)\end{array}$ \\
\hline Hole 229 & & & & & & \\
$2-1,95$ & 47.5 & 39.1 & 64.6 & - & 1.62 & 2.70 \\
$2-2,99$ & 49.5 & 29.0 & 53.5 & - & 1.81 & 2.70 \\
$2-2,105$ & 49.6 & 34.9 & 60.3 & - & 1.69 & 2.70 \\
$2-3,110$ & 51.1 & 34.3 & 60.1 & - & 1.70 & 2.70 \\
$2-4,125$ & 52.7 & 34.3 & 59.6 & - & 1.71 & 2.70 \\
$2-6,50$ & 55 & 34.2 & 59.5 & - & 1.71 & 2.70 \\
$3-1,10$ & 93.1 & 34.9 & 60.3 & - & 1.69 & 2.70 \\
$3-2,85$ & 95.3 & 36.7 & 62.2 & 64.0 & 1.66 & 2.70 \\
$3-3,100$ & 97 & 35.6 & 61.0 & - & 1.68 & 2.70 \\
$3-4,90$ & 98.4 & 33.6 & 58.9 & - & 1.72 & 2.70 \\
$3-5,25$ & 99.2 & 28.6 & 53.0 & 64.7 & 1.82 & 2.70 \\
$3-6,70$ & 101.2 & 34.6 & 60.0 & & 1.70 & 2.70 \\
$4-1,40$ & 102.4 & 25.9 & 49.5 & 71.8 & 1.87 & 2.70 \\
$4-3,120$ & 106.2 & 31.6 & 56.6 & 74.2 & 1.76 & 2.70 \\
$4-5,25$ & 108.3 & 35.3 & 60.7 & 77.2 & 1.69 & 2.70 \\
& & & & & & \\
\hline
\end{tabular}


TABLE 7 - Continued

\begin{tabular}{|c|c|c|c|c|c|c|}
\hline $\begin{array}{l}\text { Core, Section, } \\
\text { Interval }(\mathrm{cm})\end{array}$ & $\begin{array}{l}\text { Estimated } \\
\text { Depth (m) }\end{array}$ & $\begin{array}{c}\mathrm{H}_{2} \mathrm{O}(\%) \\
\text { (Lab.) }\end{array}$ & \multicolumn{2}{|c|}{ Porosity $(\%)$} & $\begin{array}{c}\text { Density } \\
\left(\mathrm{g} / \mathrm{cm}^{3}\right) \\
(\mathrm{Lab} .)\end{array}$ & $\begin{array}{l}\text { Grain } \\
\text { Density } \\
\left(\mathrm{g} / \mathrm{cm}^{3}\right)\end{array}$ \\
\hline \multicolumn{7}{|l|}{ Hole 229A } \\
\hline $\begin{array}{l}1-1,110 \\
1-2,94 \\
1-3,20 \\
1-4,120 \\
1-5,80 \\
1-6,42\end{array}$ & $\begin{array}{l}20.1 \\
21.4 \\
22.2 \\
24.7 \\
25.8 \\
26.9\end{array}$ & $\begin{array}{l}51.2 \\
41.8 \\
45.6 \\
41.7 \\
41.0 \\
23.4\end{array}$ & $\begin{array}{l}75.3 \\
67.2 \\
70.7 \\
67.1 \\
66.5 \\
46.1\end{array}$ & $\begin{array}{l}76.3 \\
72.6 \\
69.6 \\
66.2 \\
60.9 \\
47.3\end{array}$ & $\begin{array}{l}1.44 \\
1.58 \\
1.52 \\
1.58 \\
1.59 \\
1.93\end{array}$ & $\begin{array}{l}2.70 \\
2.70 \\
2.70 \\
2.70 \\
2.70 \\
2.70\end{array}$ \\
\hline $\begin{array}{l}2-2,110 \\
2-3,110 \\
2-4,80 \\
2-5,73\end{array}$ & $\begin{array}{l}30.6 \\
32.1 \\
33.3 \\
34.7\end{array}$ & $\begin{array}{l}24.3 \\
33.2 \\
35.2 \\
32.2\end{array}$ & $\begin{array}{l}59.6 \\
58.4 \\
60.6 \\
57.3\end{array}$ & $\begin{array}{l}61.9 \\
62.8 \\
64.7 \\
60.6\end{array}$ & $\begin{array}{l}1.71 \\
1.73 \\
1.69 \\
1.74\end{array}$ & $\begin{array}{l}2.70 \\
2.70 \\
2.70 \\
2.70\end{array}$ \\
\hline $\begin{array}{l}3-2,52 \\
3-2,135 \\
3-6,140\end{array}$ & $\begin{array}{l}39 \\
39.8 \\
45.9\end{array}$ & $\begin{array}{l}39.0 \\
38.9 \\
37.6\end{array}$ & $\begin{array}{l}64.5 \\
64.4 \\
63.1\end{array}$ & $\begin{array}{l}76.5 \\
79.6 \\
76.8\end{array}$ & $\begin{array}{l}1.62 \\
1.63 \\
1.65\end{array}$ & $\begin{array}{l}2.70 \\
2.70 \\
2.70\end{array}$ \\
\hline $\begin{array}{l}4-2,145 \\
4-4,50 \\
4-6,105\end{array}$ & $\begin{array}{l}58.9 \\
61 \\
64.5\end{array}$ & $\begin{array}{l}32.2 \\
30.2 \\
32.5\end{array}$ & $\begin{array}{l}57.3 \\
54.9 \\
57.6\end{array}$ & $\begin{array}{c}60.0 \\
- \\
60.2\end{array}$ & $\begin{array}{l}1.74 \\
1.78 \\
1.74\end{array}$ & $\begin{array}{l}2.70 \\
2.70 \\
2.70\end{array}$ \\
\hline $\begin{array}{l}5-3,101 \\
5-6,111\end{array}$ & $\begin{array}{l}69 \\
73.6\end{array}$ & $\begin{array}{l}34.5 \\
28.9\end{array}$ & $\begin{array}{l}59.8 \\
53.3\end{array}$ & $(6 \overline{2} .4)$ & $\begin{array}{l}1.70 \\
1.81\end{array}$ & $\begin{array}{l}2.70 \\
2.70\end{array}$ \\
\hline $\begin{array}{l}6-2,140 \\
6-3,100 \\
6-4,100 \\
6-5,140 \\
6-6,100\end{array}$ & $\begin{array}{l}76.9 \\
78 \\
79.5 \\
81.4 \\
82.5\end{array}$ & $\begin{array}{l}34.9 \\
33.9 \\
35.5 \\
38.1 \\
33.7\end{array}$ & $\begin{array}{l}60.3 \\
59.3 \\
61.1 \\
63.9 \\
59.3\end{array}$ & $\begin{array}{c}61.7 \\
\overline{\overline{2}} \\
6 \overline{2.8} \\
\overline{64.8}\end{array}$ & $\begin{array}{l}1.69 \\
1.72 \\
1.69 \\
1.65 \\
1.73\end{array}$ & $\begin{array}{l}2.70 \\
2.71 \\
2.72 \\
2.73 \\
2.74\end{array}$ \\
\hline $\begin{array}{l}7-3,80 \\
7-4,110 \\
7-5,116 \\
7-6,140\end{array}$ & $\begin{array}{l}86.8 \\
88.6 \\
90.2 \\
91.9\end{array}$ & $\begin{array}{l}42.8 \\
42.7 \\
33.9 \\
37.1\end{array}$ & $\begin{array}{l}68.6 \\
68.6 \\
59.8 \\
63.3\end{array}$ & $\begin{array}{c}\overline{75.2} \\
\overline{63.2}\end{array}$ & $\begin{array}{l}1.57 \\
1.58 \\
1.73 \\
1.67\end{array}$ & $\begin{array}{l}2.75 \\
2.76 \\
2.77 \\
2.78\end{array}$ \\
\hline $\begin{array}{l}8-1,80 \\
8-3,20-30\end{array}$ & $\begin{array}{l}113.8 \\
117\end{array}$ & $\begin{array}{l}30.7 \\
22.1\end{array}$ & $\begin{array}{l}56.4 \\
44.4\end{array}$ & $\overline{-}$ & $\begin{array}{l}1.80 \\
1.97\end{array}$ & $\begin{array}{l}2.79 \\
2.72\end{array}$ \\
\hline $\begin{array}{l}9-1,60 \\
9-2,57\end{array}$ & $\begin{array}{l}122.7 \\
124.1\end{array}$ & $\begin{array}{l}15.7 \\
30.6\end{array}$ & $\begin{array}{l}34.5 \\
55.9\end{array}$ & $\overline{77.0}$ & $\begin{array}{l}2.15 \\
1.79\end{array}$ & $\begin{array}{l}2.74 \\
2.75\end{array}$ \\
\hline $\begin{array}{l}10-4,120 \\
10-6,135\end{array}$ & $\begin{array}{l}136.7 \\
139.8\end{array}$ & $\begin{array}{l}30.6 \\
36.0\end{array}$ & $\begin{array}{l}55.9 \\
61.9\end{array}$ & $\overline{70.4}$ & $\begin{array}{l}1.79 \\
1.69\end{array}$ & $\begin{array}{l}2.75 \\
2.75\end{array}$ \\
\hline $\begin{array}{l}12-1,140 \\
12-2,120 \\
12-3,100 \\
12-4,100 \\
12-5,135\end{array}$ & $\begin{array}{l}150.4 \\
151.7 \\
153 \\
154.5 \\
158\end{array}$ & $\begin{array}{l}32.3 \\
35.4 \\
32.9 \\
32.5 \\
26.0\end{array}$ & $\begin{array}{l}57.9 \\
61.3 \\
58.6 \\
58.2 \\
50.2\end{array}$ & $\begin{array}{c}60.2 \\
73.7 \\
- \\
\overline{-} \\
81.2\end{array}$ & $\begin{array}{l}1.76 \\
1.70 \\
1.75 \\
1.76 \\
1.89\end{array}$ & $\begin{array}{l}2.75 \\
2.75 \\
2.76 \\
2.76 \\
2.76\end{array}$ \\
\hline $\begin{array}{l}13-3,60 \\
13-5,170 \\
13-6,10\end{array}$ & $\begin{array}{l}163 \\
165 \\
167\end{array}$ & $\begin{array}{l}31.4 \\
29.8 \\
30.7\end{array}$ & $\begin{array}{l}56.9 \\
55.0 \\
56.1\end{array}$ & $\begin{array}{c}62.3 \\
- \\
-\end{array}$ & $\begin{array}{l}1.78 \\
1.81 \\
1.79\end{array}$ & $\begin{array}{l}2.76 \\
2.76 \\
2.76\end{array}$ \\
\hline $14-2,105$ & 170 & 26.7 & 51.2 & 60.4 & 1.88 & 2.77 \\
\hline $\begin{array}{l}15-1,120 \\
15-3,125 \\
15-5,112 \\
15-6,85\end{array}$ & $\begin{array}{l}177 \\
181 \\
183 \\
185\end{array}$ & $\begin{array}{l}29.0 \\
19.9 \\
30.2 \\
27.6\end{array}$ & $\begin{array}{l}54.1 \\
41.6 \\
55.6 \\
52.4\end{array}$ & $\begin{array}{l}- \\
\overline{-} \\
-\end{array}$ & $\begin{array}{l}1.83 \\
2.05 \\
1.81 \\
1.86\end{array}$ & $\begin{array}{l}2.77 \\
2.77 \\
2.77 \\
2.77\end{array}$ \\
\hline $\begin{array}{l}16-2,130 \\
16-4,130 \\
16-6,102\end{array}$ & $\begin{array}{l}188 \\
191 \\
194\end{array}$ & $\begin{array}{l}31.3 \\
30.4 \\
28.2\end{array}$ & $\begin{array}{l}56.9 \\
55.9 \\
53.2\end{array}$ & $\begin{array}{c}67.7 \\
- \\
-\end{array}$ & $\begin{array}{l}1.78 \\
1.80 \\
1.85\end{array}$ & $\begin{array}{l}2.77 \\
2.77 \\
2.77\end{array}$ \\
\hline $\begin{array}{l}18-2,140 \\
18-4,120\end{array}$ & $\begin{array}{l}205 \\
211\end{array}$ & $\begin{array}{c}18.4 \\
(51.6) ?\end{array}$ & $\begin{array}{c}39.2 \\
(76.2) ?\end{array}$ & $\begin{array}{l}- \\
-\end{array}$ & $\begin{array}{l}2.09 \\
(1.45) ?\end{array}$ & $\begin{array}{l}2.77 \\
2.77\end{array}$ \\
\hline
\end{tabular}

Note: See Table 4 for detailed explanations. 
TABLE 8

Comparison of GRAPE Values for Porosity ${ }^{a}$

\begin{tabular}{|c|c|c|}
\hline $\begin{array}{l}\text { Sample Interval } \\
\text { (Depth in m) }\end{array}$ & $\mathrm{L}$ & $\mathrm{S}$ \\
\hline \multicolumn{3}{|l|}{ Site 225} \\
\hline $\begin{array}{l}1-1,1.28 \\
1-2,1.93 \\
1-5,6.46 \\
1-6,7.61\end{array}$ & $\begin{array}{l}77.7 \\
73.5 \\
73.2 \\
76.6\end{array}$ & $\begin{array}{l}85.7 \\
70.6 \\
71.4 \\
78.8\end{array}$ \\
\hline $\begin{array}{l}3-1,19.0 \\
3-2,(20) \\
3-3,(22) \\
3-4,(22.5)\end{array}$ & $\begin{array}{c}- \\
55.0 \\
50.2 \\
-\end{array}$ & $\begin{array}{l}56.4 \\
54.2 \\
50.5 \\
55.9\end{array}$ \\
\hline $\begin{array}{l}4-1,(23) \\
4-2,(24.5) \\
4-3,(26) \\
4-4,(27.5) \\
4-5,(29.8) \\
4-5,30.1 \\
4-5,30.5 \\
4-6,30.5\end{array}$ & $\begin{array}{c}- \\
- \\
- \\
\overline{-} \\
71.6 \\
71.6 \\
46.5\end{array}$ & $\begin{array}{l}62.3 \\
51.8 \\
50.7 \\
51.1 \\
57.1 \\
57.1 \\
57.1 \\
53.3\end{array}$ \\
\hline $\begin{array}{l}5-3,30.8 \\
5-4,33.0 \\
5-5,34.4 \\
5-6,(35) \\
5-6,(36)\end{array}$ & $\begin{array}{c}49.1 \\
50.5 \\
52.1 \\
\overline{54.1}\end{array}$ & $\begin{array}{l}50.3 \\
55.5 \\
55.1 \\
53.7 \\
53.7\end{array}$ \\
\hline $\begin{array}{l}6-1,36.7 \\
6-5,43.2 \\
6-6,44.6\end{array}$ & $\begin{array}{l}53.6 \\
52.4 \\
55.3\end{array}$ & $\begin{array}{l}53.7 \\
54.1 \\
55.1\end{array}$ \\
\hline $8-3,48.8$ & 60.6 & 61.4 \\
\hline $\begin{array}{l}9-3,(57) \\
9-4,58.9 \\
9-5,60.7 \\
9-6,62.1\end{array}$ & $\begin{array}{l}(58.8) \\
52.5 \\
67.8 \\
47.6\end{array}$ & $\begin{array}{l}47.3 \\
56.9 \\
65.2 \\
50.3\end{array}$ \\
\hline $10-2,54.5$ & 54.5 & 60.7 \\
\hline $11-4,76.5$ & $(62.1)$ & 62.3 \\
\hline $12-1,78.1$ & 64.7 & 65.9 \\
\hline $13-6,85.0$ & 65.7 & 63.7 \\
\hline $\begin{array}{l}14-1,87.0 \\
14-1,87.1 \\
14-2,88.8 \\
14-4,90.6\end{array}$ & $\begin{array}{l}48.8 \\
53.0 \\
70.1 \\
69.6\end{array}$ & $\begin{array}{l}52.3 \\
53.3 \\
60.4 \\
55.8\end{array}$ \\
\hline $15-2,97.3$ & 59.7 & 53.7 \\
\hline $\begin{array}{l}16-2,106.3 \\
16-3,108\end{array}$ & $\begin{array}{c}56.8 \\
(40.9)\end{array}$ & $\begin{array}{l}53.2 \\
51.3\end{array}$ \\
\hline $\begin{array}{l}17-2,114.9 \\
17-3,116.5 \\
17-4,118.8\end{array}$ & $\begin{array}{l}49.1 \\
51.4 \\
47.6\end{array}$ & $\begin{array}{l}50.6 \\
52.5 \\
53.6\end{array}$ \\
\hline $18-1,122.6$ & 51.6 & 54.9 \\
\hline $\begin{array}{l}19-1,132.4 \\
19-4,135.7\end{array}$ & $\begin{array}{l}53.0 \\
63.1\end{array}$ & $\begin{array}{l}53.5 \\
65.0\end{array}$ \\
\hline $20-1,140.4$ & - & 74.1 \\
\hline $21-3,152.2$ & - & 61.4 \\
\hline $22-5,164.5$ & 56.3 & 52.8 \\
\hline $23-1,168.4$ & 33.9 & 51.5 \\
\hline $24-1,177.5$ & 15.5 & 45.5 \\
\hline $26-1,194.3$ & - & 44.5 \\
\hline $\begin{array}{l}27-1,(203.7) \\
27-2,305.3\end{array}$ & $\overline{19.8}$ & $\begin{array}{l}20.9 \\
39.8\end{array}$ \\
\hline $29-1,(222)$ & - & 30.8 \\
\hline
\end{tabular}

TABLE 8 - Continued

\begin{tabular}{|c|c|c|}
\hline $\begin{array}{l}\text { Sample Interval } \\
\text { (Depth in } \mathrm{m} \text { ) }\end{array}$ & $\mathrm{L}$ & $\mathrm{S}$ \\
\hline \multicolumn{3}{|l|}{ Site 227} \\
\hline $\begin{array}{l}3-1,27.2 \\
3-1,28.5\end{array}$ & $\begin{array}{l}62.1 \\
44.5\end{array}$ & $\begin{array}{l}59.1 \\
59.1\end{array}$ \\
\hline $5-2,38.0$ & 65.8 & 61.9 \\
\hline $\begin{array}{l}6-1,45.7 \\
6-1,45.8 \\
6-2,47.4\end{array}$ & $\begin{array}{l}45.8 \\
62.6 \\
51.5\end{array}$ & $\begin{array}{l}52.4 \\
52.4 \\
51.3\end{array}$ \\
\hline $10-2,75.0$ & 52.7 & 51.6 \\
\hline $13-1,90.3$ & 75.2 & 65.2 \\
\hline $\begin{array}{l}16-1,114.0 \\
16-2,114.2\end{array}$ & $\begin{array}{l}36.3 \\
54.8\end{array}$ & $\begin{array}{l}52.7 \\
56.8\end{array}$ \\
\hline $\begin{array}{l}17-1,123.1 \\
17-2,124.9\end{array}$ & $\begin{array}{l}68.6 \\
62.4\end{array}$ & $\begin{array}{l}53.9 \\
56.6\end{array}$ \\
\hline $18-1,132.3$ & 42.3 & 57.2 \\
\hline $\begin{array}{l}19-1,141.0 \\
1903,143.2 \\
19-3,143.6\end{array}$ & $\begin{array}{l}67.8 \\
49.7 \\
56.1\end{array}$ & $\begin{array}{l}67.6 \\
52.7 \\
52.7\end{array}$ \\
\hline $\begin{array}{l}20-2,151.3 \\
20-3,153.0 \\
20-4,154.3 \\
20-5,155.8\end{array}$ & $\begin{array}{l}60.4 \\
49.5 \\
42.8 \\
42.5\end{array}$ & $\begin{array}{l}53.6 \\
50.6 \\
48.2 \\
48.5\end{array}$ \\
\hline $\begin{array}{l}22-2,160.4 \\
22-3,(161.8) \\
22-4,163.2\end{array}$ & $\begin{array}{l}50.7 \\
42.5\end{array}$ & $\begin{array}{l}45.9 \\
45.9 \\
47.7\end{array}$ \\
\hline $24-6,184.0$ & 44.3 & 49.0 \\
\hline $25-2,186.9$ & 50.9 & 58.9 \\
\hline $\begin{array}{l}28-2,214.0 \\
28-3,215.4\end{array}$ & $\begin{array}{l}52.6 \\
64.9\end{array}$ & $\begin{array}{l}66.8 \\
60.3\end{array}$ \\
\hline \multicolumn{3}{|l|}{ Site 228} \\
\hline $\begin{array}{l}2-2,17.0 \\
2-3,18.4\end{array}$ & $\begin{array}{l}44.6 \\
49.6\end{array}$ & $\begin{array}{l}44.5 \\
49.3\end{array}$ \\
\hline $3-1,24.5$ & 66.7 & 54.1 \\
\hline $\begin{array}{l}4-1,24.4 \\
4-2,25.9 \\
4-3,28.0 \\
4-4,29.5 \\
4-5,30.8\end{array}$ & $\begin{array}{l}62.8 \\
48.2 \\
53.9 \\
59.6 \\
48.9\end{array}$ & $\begin{array}{l}55.7 \\
50.7 \\
51.8 \\
61.8 \\
46.9\end{array}$ \\
\hline $\begin{array}{l}5-3,37.0 \\
5-4,38.7\end{array}$ & $\begin{array}{l}55.9 \\
46.0\end{array}$ & $\begin{array}{l}52.7 \\
49.3\end{array}$ \\
\hline $\begin{array}{l}6-2,44.3 \\
6-3,46.4 \\
6-4,47.2 \\
6-5,49.1 \\
6-6,50.0\end{array}$ & $\begin{array}{l}49.7 \\
53.9 \\
51.6 \\
43.4 \\
42.8\end{array}$ & $\begin{array}{l}53.1 \\
57.2 \\
54.1 \\
47.1 \\
45.9\end{array}$ \\
\hline $\begin{array}{l}7-1,51.4 \\
7-2,53.1 \\
7-4,56.2 \\
7-5,58.0 \\
7-6,58.9\end{array}$ & $\begin{array}{l}49.7 \\
47.4 \\
49.3 \\
47.4 \\
39.7\end{array}$ & $\begin{array}{l}50.6 \\
49.4 \\
48.8 \\
46.2 \\
40.7\end{array}$ \\
\hline $8-3,63.8$ & 48.3 & 49.1 \\
\hline $10-6,77.2$ & 39.0 & 44.0 \\
\hline $11-4,83.4$ & 39.1 & 39.8 \\
\hline $12-4,92.9$ & 51.4 & 53.7 \\
\hline $13-2,98.6$ & 41.6 & 44.8 \\
\hline
\end{tabular}


TABLE 8-Continued

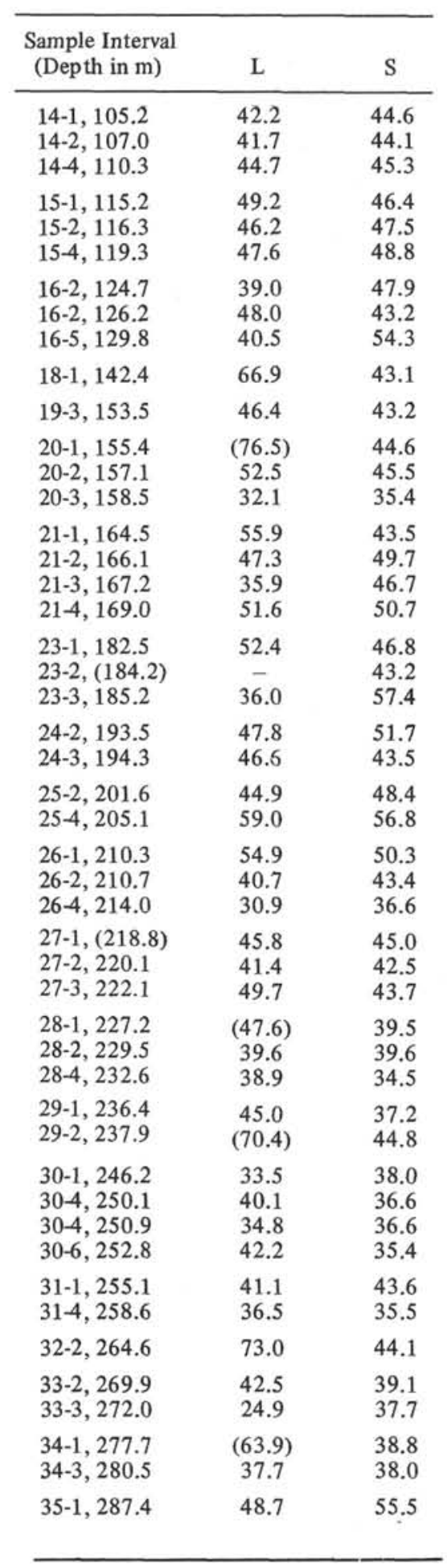

TABLE 8-Continued

\begin{tabular}{lcc}
\hline $\begin{array}{c}\text { Sample Interval } \\
\text { (Depth in m) }\end{array}$ & L & S \\
\hline & & \\
Hole 229 & & \\
3-2, 95.4 & 64.0 & 68.0 \\
3-5, 99.2 & 64.7 & 73.7 \\
$4-1,102.4$ & 71.8 & 74.1 \\
$4-3,106.2$ & 74.2 & 78.0 \\
$4-5,108.3$ & 77.2 & 79.8
\end{tabular}

Hole 229A

\begin{tabular}{lcc} 
1-1, 20.1 & 76.3 & 69.6 \\
$1-2,21.4$ & 72.6 & 66.0 \\
$1-3,22.2$ & 69.5 & 68.0 \\
$1-4,24.7$ & 66.2 & 54.8 \\
$1-5,25.8$ & 60.9 & 55.9 \\
$1-6,26.9$ & 47.3 & 49.9 \\
& & \\
$2-2,30.6$ & 61.9 & 63.2 \\
$2-3,32.1$ & 62.8 & 62.2 \\
$2-4,33.3$ & 64.7 & 62.4 \\
$2-5,34.7$ & 60.6 & 63.5 \\
& & \\
$3-2,39.0$ & 76.5 & 70.9 \\
$3-2,39.9$ & 79.6 & 70.9 \\
$3-4,42.4$ & 70.5 & 70.3 \\
$3-6,45.2$ & 76.8 & 71.4 \\
$4-2,58.9$ & 60.0 & 63.8 \\
$4-4,61.0$ & 57.7 & 63.5 \\
$4-6,64.5$ & 60.2 & 59.0 \\
$5-6,73.6$ & $(62.4)$ & 60.5 \\
& & \\
$6-2,76.9$ & 61.7 & 66.7 \\
$6-4,79.5$ & 62.8 & 64.3 \\
$6-6,82.5$ & 64.8 & 65.0 \\
$7-4,88.6$ & 75.2 & 71.6 \\
$7-6,91.9$ & 63.2 & 69.8 \\
$9-2,124.1$ & 77.0 & 69.8 \\
$10-6,139.8$ & 70.4 & 73.8 \\
& & \\
$12-1,150.4$ & 60.2 & 66.3 \\
$12-2,151.7$ & 73.9 & 63.3 \\
$12-5,156.3$ & 81.2 & 69.1 \\
$13-3,161.6$ & 62.3 & 62.5 \\
$14-2,169.5$ & 60.4 & 69.4 \\
$16-2,187.8$ & 67.7 & - \\
\hline L=1ocal; S section average. Porosities \\
are in percent. & & \\
& &
\end{tabular}


TABLE 9

Statistical Comparison of Porosities Determined

from Water Content, Grain Denxity $(x)$, and Gamma Ray Attenuation (GRAPE) $(y)$

\begin{tabular}{lcccc}
\hline & 225 & 227 & 228 & 229 \\
\hline $\bar{x}$ & 52.3 & 45.3 & 42.3 & 59.7 \\
$\bar{y}$ & 55.0 & 53.9 & 47.4 & 67.2 \\
$S_{x y}$ & 9.24 & 8.31 & 9.16 & 6.88 \\
$\left(S_{x y}\right)^{2}$ & 85.3 & 69.0 & 83.9 & 47.3 \\
$r$ & 0.68 & 0.57 & 0.30 & 0.38 \\
$n$ & 41 & 28 & 72 & 36 \\
$a$ & 23.0 & 8.9 & 36.0 & 39.0 \\
$b$ & 0.61 & 0.99 & 0.27 & 0.49 \\
$S_{a}$ & 5.52 & 12.5 & 4.34 & 11.4 \\
$S_{b}$ & 0.102 & 0.273 & 0.100 & 0.190 \\
$t_{a}$ & 4.16 & 0.7154 & 8.30 & 3.42 \\
$t_{b}$ & -3.79 & -1.029 & -7.35 & -2.67 \\
$t_{0.975}$ & 2.02 & 2.06 & 2.00 & 2.03 \\
\hline
\end{tabular}

Note: Correlation between $\mathrm{x}$ and $\mathrm{y}$ values is evaluated by Student's $t$ distribution for sample pairs and for slope and intercept for an equation of the form $y=a+b x$.

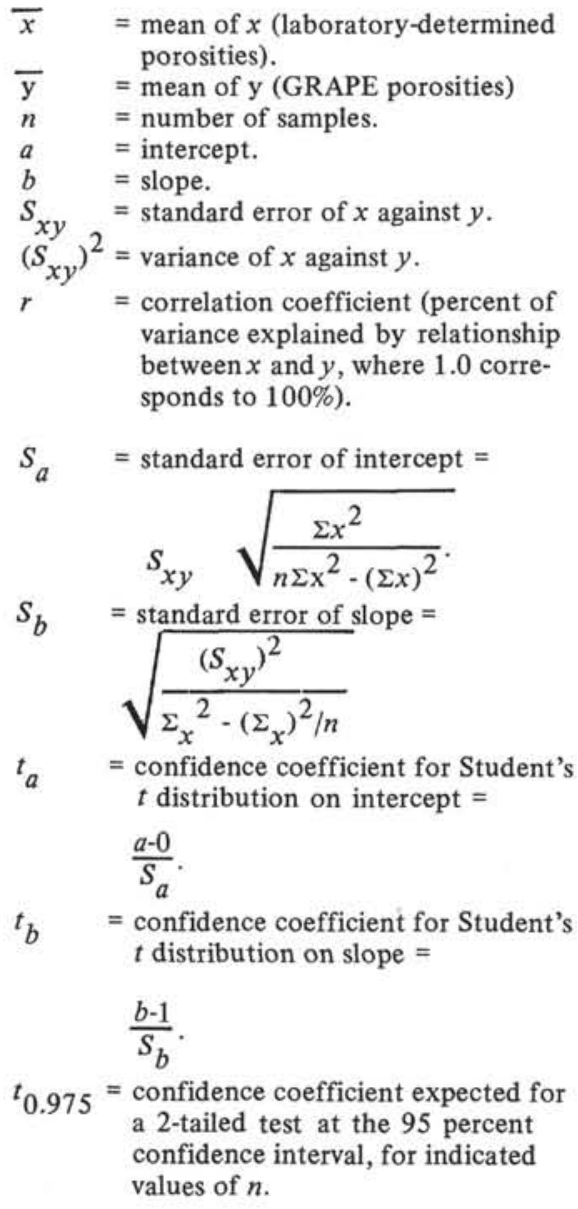


POROSITY (\%)

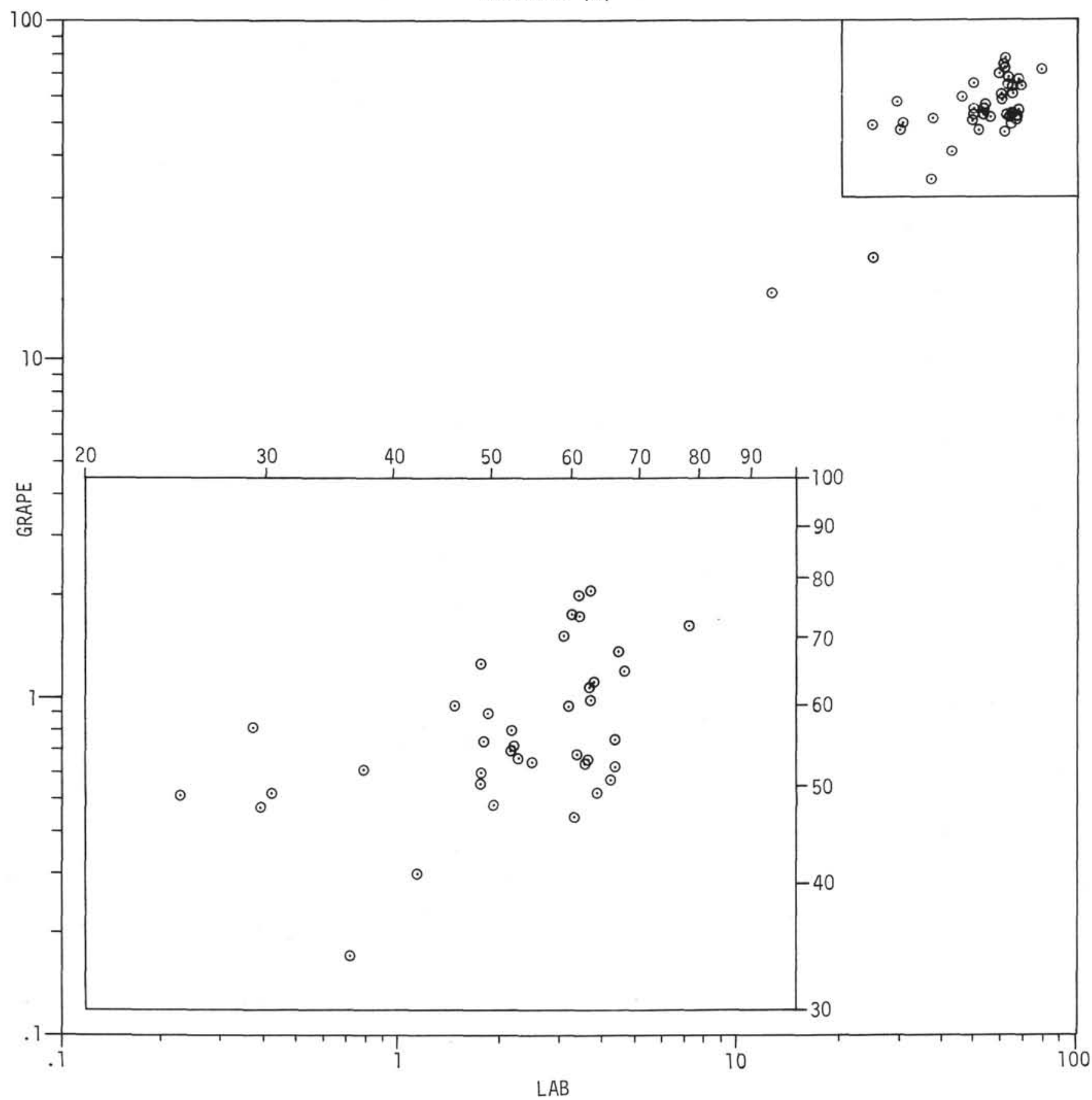

Figure 1. Plot of laboratory and GRAPE porosity values, Site 225. Expanded plot covers area shown in inset lines. 
F. MANHEIM, L. DWIGHT, R. BELASTOCK

POROSITY (\%)

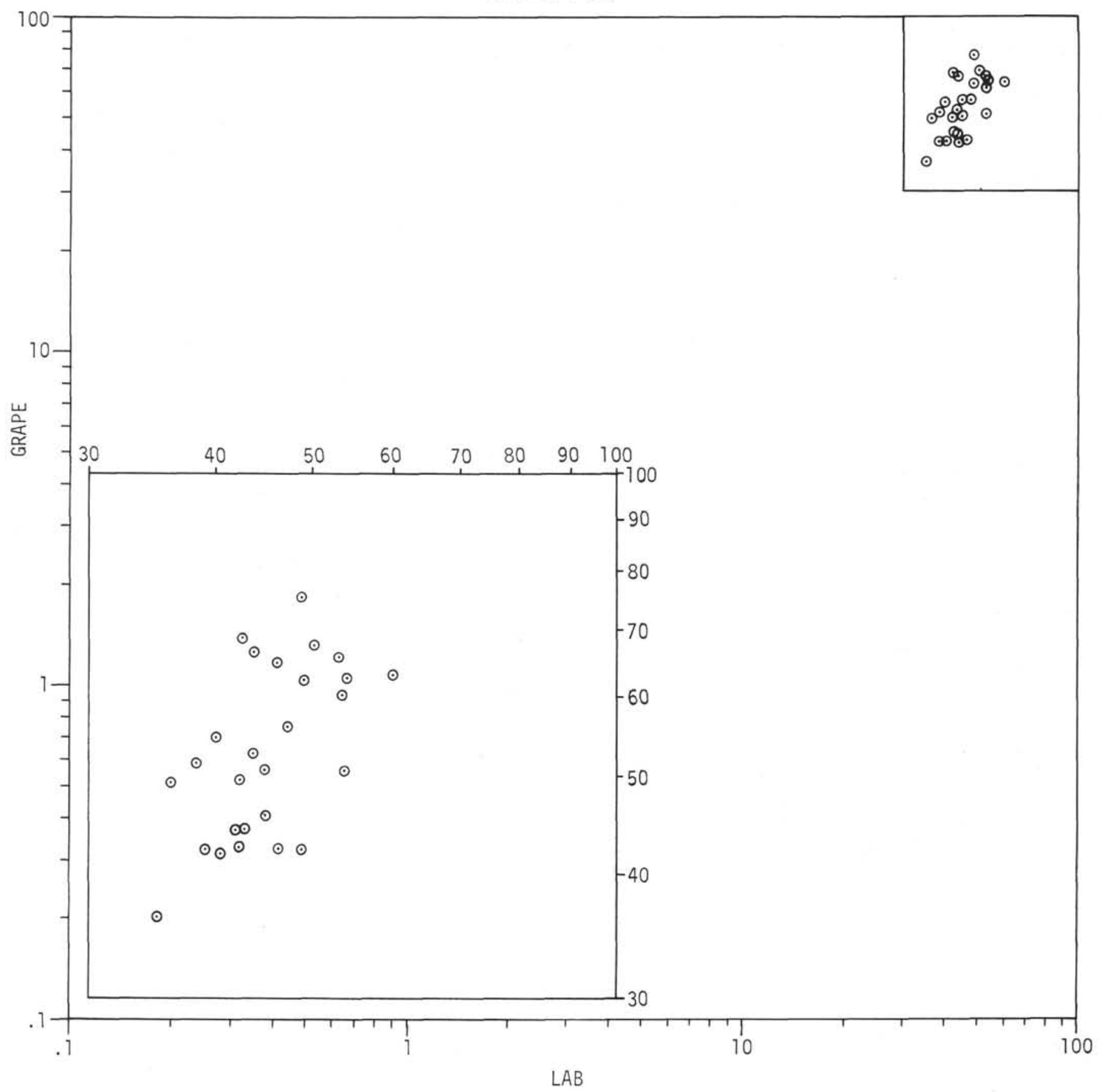

Figure 2. Plot of laboratory and GRAPE porosity values, Site 227. 
POROSITY (\%)

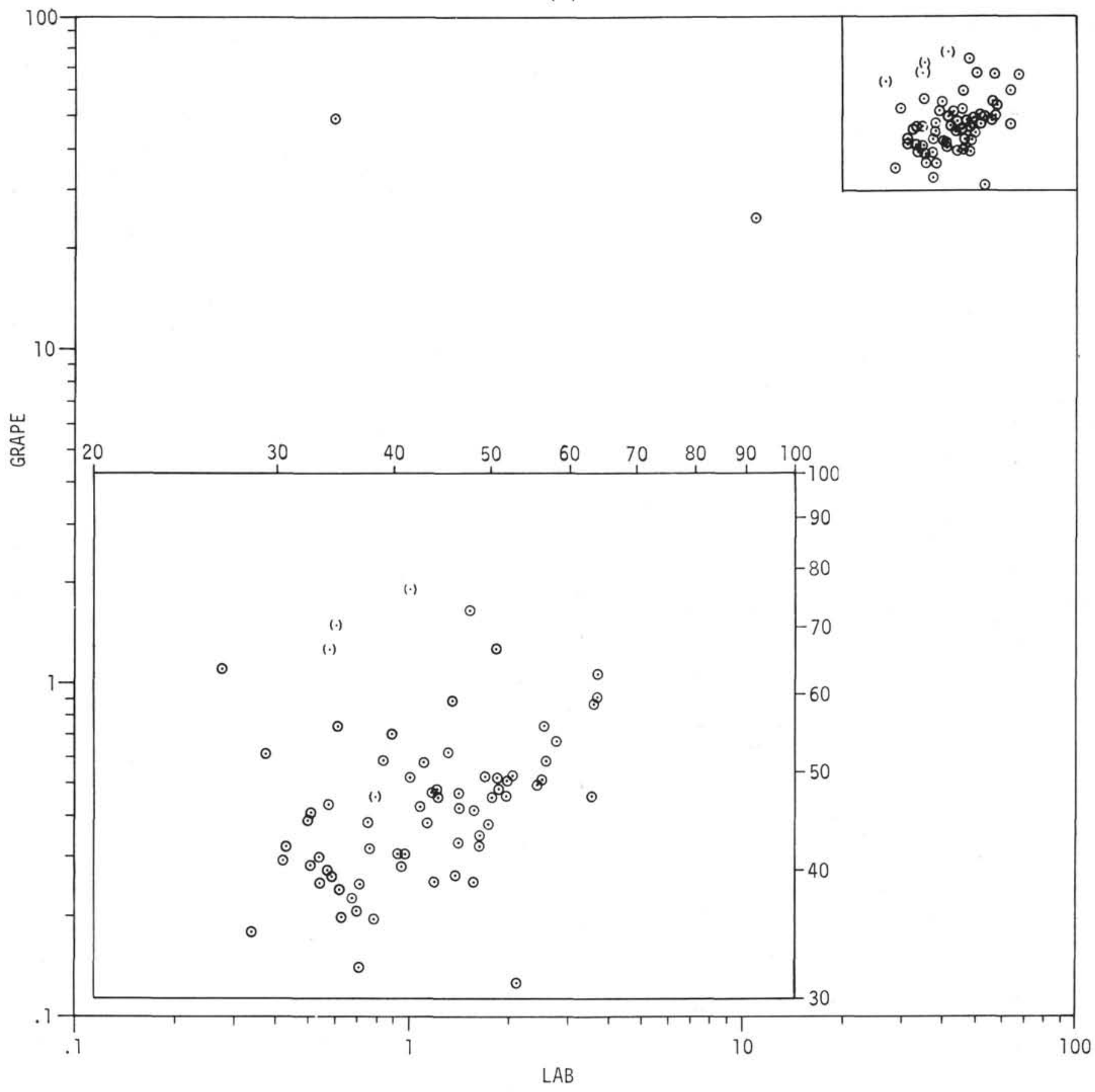

(.) approx. value only

Figure 3. Plot of laboratory and GRAPE porosity values, Site 228. 
F. MANHEIM, L. DWIGHT, R. BELASTOCK

POROSITY (\%)

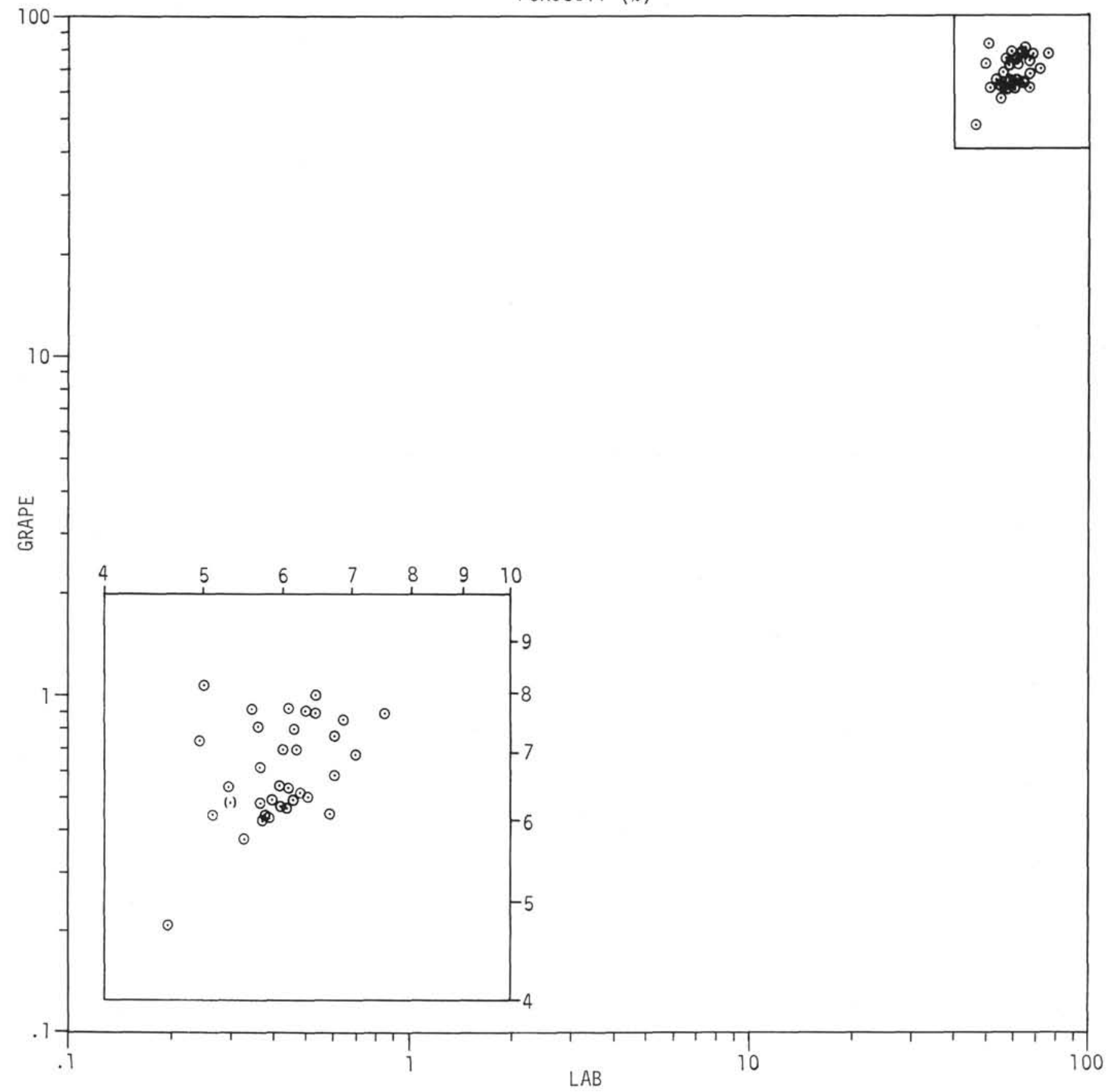

Figure 4. Plot of laboratory and GRAPE porosity values, Site 229. 


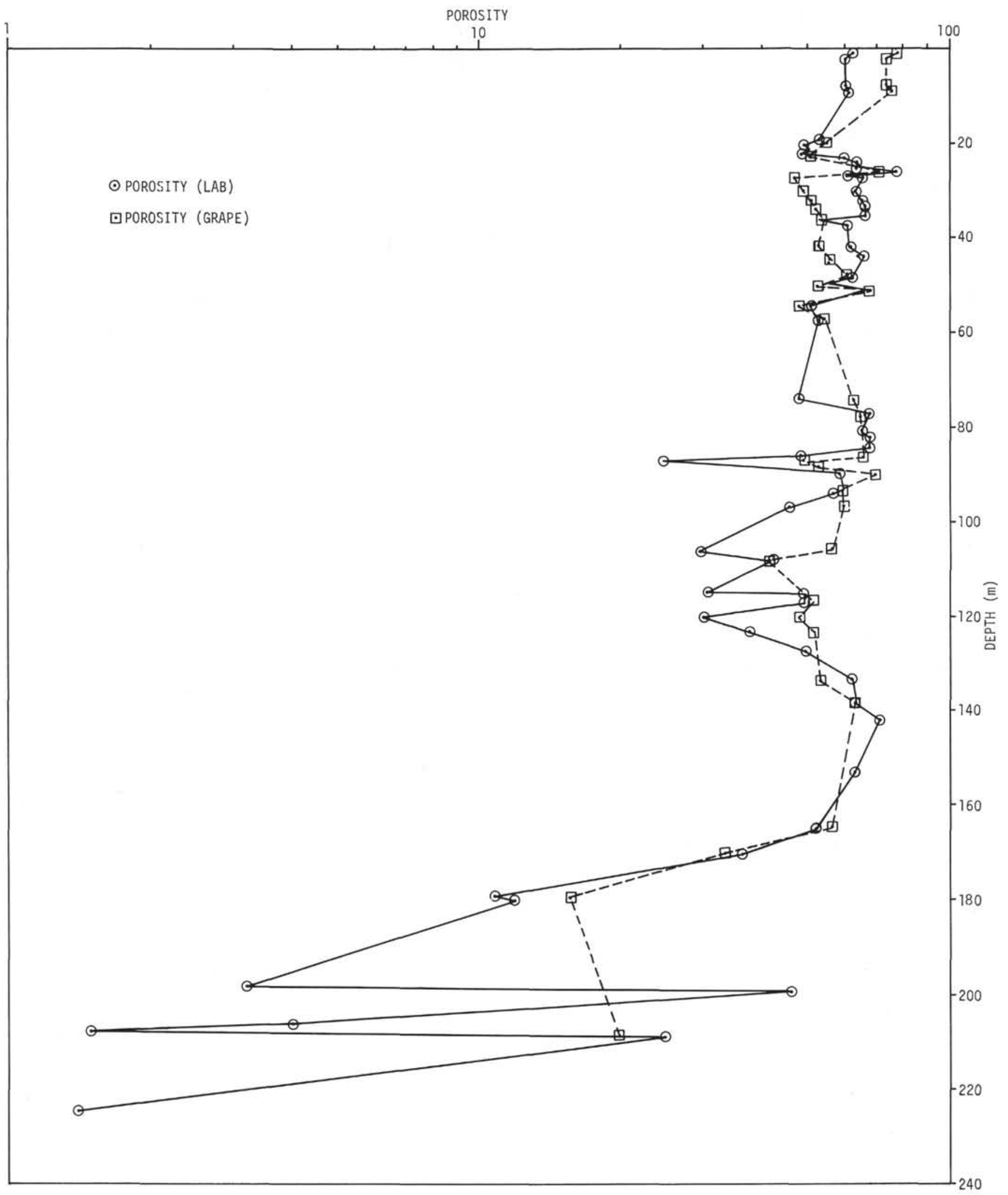

Figure 5. Plot of laboratory and GRAPE porosity values with depth, Site 225 . 